\title{
Nitrate reduction potential of a fractured Middle Triassic carbonate aquifer in Southwest Germany
}

\author{
Karsten Osenbrück ${ }^{1}$ (D) Eva Blendinger ${ }^{1} \cdot$ Carsten Leven $^{1} \cdot$ Hermann Rügner $^{1} \cdot$ Michael Finkel $^{1} \cdot$ Natalia Jakus $^{1}$. \\ Hartmut Schulz ${ }^{1}$ Peter Grathwohl ${ }^{1}$
}

Received: 21 May 2021 / Accepted: 14 October 2021 / Published online: 7 December 2021

(C) The Author(s) 2021

\begin{abstract}
Nitrate reduction constitutes an important natural mechanism to mitigate the widespread and persistent nitrate contamination of groundwater resources. In fractured aquifers, however, the abundance and accessibility of electron donors and their spatial correlation with groundwater flow paths are often poorly understood. In this study, the nitrate reduction potential of a fractured carbonate aquifer in the Upper Muschelkalk of SW Germany was investigated, where denitrification is due to the oxidation of ferrous iron and reduced sulfur. Petrographical analyses of rock samples revealed concentrations of synsedimentary and diagenetically formed pyrite ranging from 1 to $4 \mathrm{wt}$.\% with only small differences between different facies types. Additional ferrous iron is available in saddle dolomites (up to $2.6 \mathrm{wt} . \%$ ), which probably were formed by tectonically induced percolation of low-temperature hydrothermal fluids. Borehole logging at groundwater wells (flowmeter, video, gamma) indicates that most groundwater flow occurs along karstified bedding planes partly located within dolomites of the shoal and backshoal facies. The high porosity (15-30\%) of these facies facilitates molecular diffusive exchange of solutes between flow paths in the fractures and the reactive minerals in the pore matrix. The high-porosity facies together with hydraulically active fractures featuring pyrite or saddle dolomite precipitates constitute the zones of highest nitrate reduction potential within the aquifer. Model-based estimates of electron acceptor/donor balances indicate that the nitrate reduction potential protecting water supply wells increases with increasing porosity of the rock matrix and decreases with increasing hydraulic conductivity (or effective fracture aperture) and spacing of the fracture network.
\end{abstract}

Keywords Fractured rocks $\cdot$ Groundwater protection $\cdot$ Nitrate $\cdot$ Carbonate facies $\cdot$ Germany

\section{Introduction}

Fractured and karstified carbonate aquifers constitute major drinking water resources worldwide (Goldscheider et al. 2020). As with other groundwater resources, carbonate aquifers are at risk of pollution by anthropogenic compounds such as nitrate (Vías et al. 2006; Husic et al. 2019). Nitrate contamination has evolved to become a global environmental and health problem (Ward et al. 2018) due to continuing expansion of agricultural production over the last few decades (Morris et al. 2003; OECD 2008). Under oxic conditions, nitrate $\left(\mathrm{NO}_{3}{ }^{-}\right)$is usually transported conservatively with percolating water or along groundwater flow paths. In

Karsten Osenbrück

karsten.osenbrueck@uni-tuebingen.de

1 Department of Geosciences, University of Tübingen, Schnarrenbergstrasse 94-96, 72076 Tübingen, Germany the absence of oxygen, $\mathrm{NO}_{3}{ }^{-}$may be degraded by microbially mediated processes, which leads to the formation of more reduced compounds such as $\mathrm{N}_{2}$ (by denitrification) or $\mathrm{NH}_{4}{ }^{+}$(by dissimilatory nitrate reduction to ammonium; Korom 1992; Kuypers et al. 2018). The reduction of nitrate constitutes an important natural mechanism for the attenuation of high $\mathrm{NO}_{3}{ }^{-}$concentrations in groundwater in general (Rivett et al. 2008) and specifically in carbonate rock aquifers (Einsiedl and Mayer 2006; Heffernan et al. 2012). Therefore, a better understanding and estimation of the nitrate reduction potential is imperative for safeguarding groundwater quality and the supply of drinking water.

The nitrate reduction potential is mainly governed by the occurrence of suitable redox conditions (e.g., low oxygen concentrations), a sufficient amount of electron donors near groundwater flow paths, and the presence and activity of microbial communities capable of coupling nitrate reduction to the oxidation of bioavailable electron donors. While 
natural organic matter (NOM) is the most common electron donor for (heterotrophic) denitrification in shallow alluvial aquifers (Smith and Duff 1988; Zarnetske et al. 2011), ferrous iron $[\mathrm{Fe}(\mathrm{II})]$ and reduced sulfur $[\mathrm{S}(-\mathrm{I})]$ bearing minerals such as pyrite were found to dominate (autotrophic) denitrification in aquifers with low amounts and limited bioavailability of NOM. This includes fractured aquifers in carbonate rocks (Baker et al. 2012; Kim et al. 2016; Opazo et al. 2016), and crystalline bedrock (Pauwels et al. 2000; Orr et al. 2016), but also porous aquifers (e.g., Schwientek et al. 2008; Zhang et al. 2013). The presence of denitrifying microorganisms within fractured carbonate aquifers was confirmed by studies investigating microbial communities in the major conduit and fracture network (Farnleitner et al. 2005; Jakus et al. 2021) or attached to the limestone rock matrix (Herrmann et al. 2017; Starke et al. 2017). However, only a few studies have provided sound estimates of the amount of electron donors available in the aquifer matrix for the observed nitrate reduction processes (e.g., Kludt et al. 2016). Particularly for fractured aquifers, detailed information on the extent of nitrate turnover and the inventory of available electron donors is usually sparse, which often limits the estimation of the nitrate reduction potential to geostatistical or stochastic modeling approaches (Rivas et al. 2017; Loschko et al. 2019).

The Middle Triassic carbonates of the Upper Muschelkalk form an important regional fractured aquifer in southwest Germany, which is used for drinking water supply. The main objective of this study was to assess and estimate the available nitrate reduction potential protecting drinking water wells and springs of the Middle Triassic carbonate aquifer, taking into account the porosities and the contents of Fe(II) and S(-I)-bearing minerals in the major sedimentological facies types of the aquifer's rock matrix.

\section{Principle approach}

To provide realistic estimates of the parameters required for the assessment of the nitrate reduction potential of the Upper Muschelkalk aquifer, first, the major sedimentological facies types of the aquifer's rock matrix were characterized with respect to hydraulically relevant features and to the content of reactive minerals. The inventory of electron donors available for nitrate reduction within the aquifer was determined by analyzing the abundance of $\mathrm{Fe}(\mathrm{II})$ and S(-I) together with the porosity of the rock matrix using thin section microscopy and EDX spectra of rock samples from the main sedimentological facies types (see sections "Type, occurrence, and characterization of reactive minerals", "Major facies types and distribution of reactive minerals", and "Evidence of reactivity"). Since nitrate (and oxygen) transport in the aquifer is mainly linked to groundwater flow along fractures, the rock matrix adjacent to these flow paths forms the major zones contributing electron donors for the potential redox processes. The location and distribution of the predominant flow paths were derived from flowmeter logs in three wells extracting groundwater from the Upper Muschelkalk. Gamma logs were used to relate the observed groundwater flow paths with the known lithological and facies profiles from quarries and drilling cores (see section "Groundwater flow paths with advective nitrate transport"). With these data and information, hydraulically active fractures could be interrelated with the measured porosity and $\mathrm{Fe}(\mathrm{II})$ and $\mathrm{S}(-\mathrm{I})$ concentrations of the respective facies in order to identify potential zones of high nitrate turnover within the aquifer (see section "Zones of high nitrate turnover in the aquifer"). Finally, nitrate degradation processes were evaluated using model simulations of the electron donor/acceptor mass balance along groundwater flow paths for the different facies types. These simulations provided estimates of the remaining nitrate reduction potential as a function of nitrate input concentrations and the time over which this nitrate input might persist (see section "Remaining nitrate reduction potential of the aquifer").

\section{Study area}

The study area "Oberes Gäu" is an intensively agriculturally used region located in Baden-Württemberg, southwest Germany. It is located near the town of Herrenberg, approximately $25 \mathrm{~km} \mathrm{SW}$ of the city of Stuttgart and $20 \mathrm{~km}$ west of the city of Tübingen (Fig. 1).

\section{Geological setting}

The up to 90-m-thick carbonates of the Upper Muschelkalk (Middle Triassic) shown in Fig. S1 of the electronic supplementary material (ESM) have been extensively investigated with respect to sedimentology (e.g., Köhrer et al. 2010; Palermo et al. 2012; Warnecke and Aigner 2019). The sedimentation area of the Upper Muschelkalk of southwest Germany is interpreted as a shallow marine stormdominated carbonate ramp (Aigner 1985). It developed on the NW margin of the Vindelician-Bohemian Massif in the semi-enclosed intracratonic Germanic Basin, which was sporadically linked to the Tethys Ocean in the south via the Silesian-Moravian (SiMo), East Carpathian (E-Ca), and the Burgundy seaways or "gates" (Ziegler 1990; Fig. 1b). The gently inclined paleoslope was dipping at less than $1^{\circ}$ to the NW into the basin. On a section from SE to NW, different facies zones from the shallow marine to the deep basin can be observed. The succession of the Upper Muschelkalk starts with the shallow marine Zwergfauna-Member and the $\mathrm{Haßmersheim-Member,} \mathrm{which} \mathrm{is} \mathrm{characterized} \mathrm{by}$ 


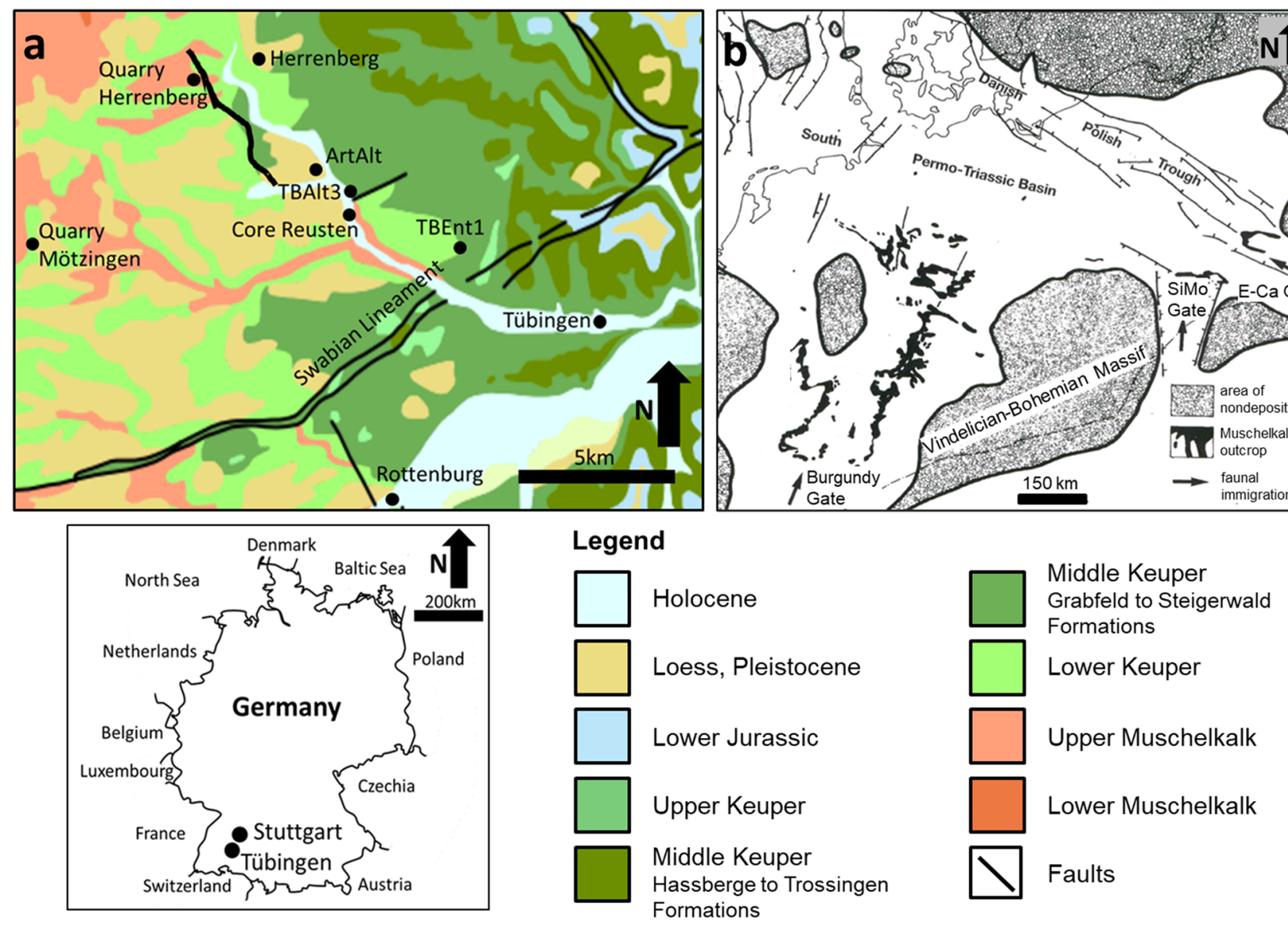

Fig. 1 a Geologic map of the study area (LGRB 2019) with major tectonic elements and location of sampling sites; b Paleogeography of the Muschelkalk (Middle Triassic; white area) in central Europe (after Hagdorn 1991). The red frame indicates the study area

a prominent clay horizon. These are followed by the ramp deposits of the Trochitenkalk Formation, an alternation of more basinal marlstones, mudstones, and crinoidal limestone beds forming an overall fining-upward sequence (Palermo et al. 2012) of stacked meter-scale stratigraphic cycles. The subsequent Meißner Formation forms an overall coarsening upward sequence (Palermo et al. 2012) made up of marlstones, fine-grained limestones, and shoal carbonates. The top of the Muschelkalk is formed by the peritidal dolomites of the Rottweil Formation ("Trigonodusdolomit"), which are overlain with a sequence boundary (Aigner and Bachmann 1992) by the clastic and gypsum deposits of the Keuper Group (Upper Triassic).

As a consequence of tectonic events, such as the rifting of the Atlantic in the Jurassic-Early Cretaceous and the formation of the Upper Rhine Graben in late Eocene-Quaternary, the area was affected by intense fracturing and brittle deformation of the sedimentary cover resulting in the gentle dipping $\left(1-3^{\circ}\right)$ of the lithostratigraphic units to the SE. Faults with horizontal and often lateral displacements up to several tens of meters, e.g. the Swabian Lineament, are trending mainly NW-SE, ENE-WSW and NNE-SSW (Reicherter et al. 2008; Schwarz 2012; Ring and Bolhar 2020). This was accompanied by the rise of hydrothermal fluids (Staude et al. 2009; Pfaff et al. 2010; Bons et al. 2014). In the study area, escaping mantle-born $\mathrm{CO}_{2}$ (Lübben and Leven 2018), which was used by D'Affonseca et al. (2020) to verify the existence of unmapped faults, might be related to these processes.

\section{Hydrogeological setting}

The limestone and dolomite rocks of the Upper Muschelkalk constitute a regional fractured aquifer of about $150 \mathrm{~km}^{2}$ in size. In the NW of the study area, the Upper Muschelkalk outcrops below a usually shallow soil cover $(0.3-1.8 \mathrm{~m})$ over a distance of $2-4 \mathrm{~km}$ and gently dips to the SE, where it is increasingly covered by low-permeability sedimentary Upper Triassic rocks (Fig. 1a). The base of the aquifer is formed by impermeable clayey subrosion residues of the evaporite-dominated formations of the Middle Muschelkalk. The uncovered part of the Upper Muschelkalk constitutes the main recharge area and karstification of the limestone rocks 
caused numerous dolines and other karstic structures (sinkholes and karstic springs) in this area. Towards the SE the fractured carbonate aquifer becomes confined or even artesian. D'Affonseca et al. (2020) report a mean bulk hydraulic conductivity of $3 \times 10^{-6} \mathrm{~m} / \mathrm{s}$ for the covered (not karstified) part of the Upper Muschelkalk aquifer, which mainly represents the fracture network of the carbonate formations. A higher mean value of $4 \times 10^{-5} \mathrm{~m} / \mathrm{s}$ was reported in Villinger (1982) if also the karstified part of the aquifer is taken into account. The porous rock matrix itself can be expected to be much less permeable and only accessible by molecular diffusion. Generally, the groundwater flow direction is from NW to SE following the dipping of the Triassic formations. In addition to karstic features, regional groundwater flow is influenced by numerous tectonic structures and their associated fault systems (D'Affonseca et al. 2020). Most fractures visible in quarries or boreholes follow the ENE-WSW and NW-SE directions of the fault zones. Spacing of the mainly subvertical fractures typically ranges between 1.5 and $5.0 \mathrm{~m}$. No reliable data on fracture apertures were available because of weathering or mechanical stress of the rock faces at quarries.

\section{Sources and cycling of nitrate}

Dominant agricultural land use (about 67\%; Visser et al. 2021) over the entire study area leads to the release of $\mathrm{NO}_{3}{ }^{-}$from inorganic fertilizers or manure into the karstic aquifer. Groundwater nitrate concentrations decline with increasing distance from the recharge area from elevated values (approximately $35 \mathrm{mg} / \mathrm{L}$ on average) to low concentrations in the range of $0-2 \mathrm{mg} / \mathrm{L}$ in the confined part of the aquifer. Dissolved organic carbon (DOC) concentrations are generally low (mean of $1.1 \mathrm{mg} / \mathrm{L}$ ), and no correlation was observed between $\mathrm{NO}_{3}{ }^{-}$and DOC concentrations (Visser et al. 2021), suggesting that electron donors other than DOC might play a role for nitrate reduction. Evidence that the decrease in nitrate is due to microbially mediated nitrate reduction coupled to oxidation of $\mathrm{Fe}(\mathrm{II})$ or $\mathrm{S}(-\mathrm{I})$ was provided by geochemical and isotopic investigations (Visser et al. 2021) and by microbial enrichment cultures (Jakus et al. 2021) from the aquifer. Nitrate concentrations of up to $80 \mathrm{mg} / \mathrm{L}$ are also present in overlying aquifers of the Lower and Middle Keuper. This suggests that dilution with nitrate-poor groundwater by mixing with groundwater from a different recharge area is unlikely to cause the low nitrate concentrations in the confined part of the Upper Muschelkalk aquifer. Moreover, tritium concentrations ranging from 6 to $16 \mathrm{TU}$ (samples collected from 2004 to 2011; unpublished data of the water supplier) indicate that most of the groundwater was recharged after the start of intense fertilizer application about 60 years ago. Access to the groundwater is provided by an artesian monitoring well (ArtAlt) and two production wells (TBEnt1, TBAlt3), which were used for flowmeter logging and chemical monitoring.

\section{Data collection and experimental methods}

\section{Petrographical analyses}

To investigate the occurrence, amount, and origin of reactive, iron- and sulfur-containing minerals in rocks of the Upper Muschelkalk, rock samples from different locations within the study area were collected from quarries near Herrenberg and Mötzingen and from a recently drilled Muschelkalk core near Reusten (Fig.1). Special care was taken during sampling to consider lithologies that vary in facies type and visible porosity and to select samples from areas with different degrees of tectonic stress. From the samples, about 30 uncovered thin sections mounted on glass-slides $26 \times 48 \mathrm{~mm}$ and $50 \times 50 \mathrm{~mm}$ and polished on grinding powder of grit size $100-1,200$ to a final thickness of $35 \mu \mathrm{m}$ were prepared. Thin sections were analyzed with a polarizing light microscope (Leitz Laborlux 12 Pol S) using transmitted and reflected light at a magnification of 50-200 according to lithology and Dunham texture (Dunham 1962), in order to (1) identify type and content of iron-bearing minerals, (2) to estimate macro-porosity and (3) to evaluate sedimentary features of the selected rock samples and identify the facies type. For porosity determination, thin sections were pretreated with blue dyed resin. Thin sections selected for energy dispersive X-ray spectroscopy (EDX) were polished with diamond suspensions of $6-15 \mu \mathrm{m}$ and $3-\mu \mathrm{m}$ grain diameter. To prevent the electrically nonconductive samples from becoming charged during electron beam bombardment, the samples were cleaned with acetone, dried and coated with a thin layer of carbon using a Sputter Coater (BAL-TEC Model SCD 005/CEA 035). Analyses of the iron minerals and matrix composition were carried out using a scanning electron microscope (LEO $1450 \mathrm{VP}$ ) and EDX-system (OXFORD Instruments INCA Energy300).

\section{Fraction of organic carbon in rock samples}

To quantify the organic carbon content $\left(f_{\text {oc }}\right)$ rock samples were crushed using a jaw crusher, dried at $60{ }^{\circ} \mathrm{C}$ in an oven, pulverized $\left(\mathrm{ZrO}_{2}\right.$ ball mill), decarbonized $(\mathrm{HCl} 16 \%)$, purged with deionized water and redried $\left(60{ }^{\circ} \mathrm{C}\right)$. Measurements were performed with an elemental analyzer (Elementar Vario EL; thermal oxidation at $950{ }^{\circ} \mathrm{C}$ and $\mathrm{CO}_{2}$ quantification using a heat conductivity detector). Results are reported in wt. \%; LOQ $=0.003$ wt. $\%$. 


\section{Chemical analyses of sulfur as proxy for pyrite concentrations}

The determination of pyrite concentrations in rock samples according to the AVS/CRS method was done at Aarhus University, Denmark. The inorganic sulfur was divided into two fractions, acid volatile sulfides (AVS): $\mathrm{H}_{2} \mathrm{~S}, \mathrm{FeS}$, and chromium reducible sulfides (CRS): $\mathrm{S}^{0}, \mathrm{FeS}_{2}$. Their digestions were performed following a two-step procedure. In a first step, AVS were distilled from a weighed amount of homogenized rock powder. In a second step, the CRS were determined in the sediment slurry remaining after AVS distillation as described by Fossing and Jorgensen (1989). The total concentration of pyrite was calculated from the total concentration of CRS assuming that pyrite was the only source of chromium-reducible inorganic sulfur in the sample.

\section{Flowmeter and video logging}

Flowmeter logging was used to identify groundwater inflow horizons and quantify the corresponding water fluxes at three groundwater wells completed in the Upper Muschelkalk aquifer (see Fig. 1 for their locations). A flowmeter with a hot wire sensor (Berghof Analytik \& Umweltengineering $\mathrm{GmbH}$, Tübingen, Germany) using the principle of anemometry (Agarwal and Olin 2014) was used to measure vertical flow rates in the 45-m-deep water supply well TBEnt 1 and in the artesian well ArtAlt in April and July 2014, respectively. The 60-m-deep ArtAlt has a completed well casing down to $19 \mathrm{~m}$ below ground surface (bgs) corresponding to the base of the Upper Triassic (Lower Keuper) sediments. The remaining $41 \mathrm{~m}$ within the Upper Muschelkalk are left unscreened as an open borehole with a diameter of $330 \mathrm{~mm}$ (from 19 to $28 \mathrm{~m} \mathrm{bgs}$ ) and $220 \mathrm{~mm}$ (from 28 to $60 \mathrm{~m} \mathrm{bgs}$ ). At the 60-m-deep water supply well TBAlt3, an impeller flowmeter (Mount Sopris Instruments, Denver, USA) was used to measure vertical flow rates in Jan 2019. Details on the construction of the wells TBEnt 1 and TBAlt3 are provided in Figs. S3 and S4 of the ESM. In total, four flowmeter $\log$ s were conducted at each well, at ArtAlt under natural artesian outflow conditions of about $6 \mathrm{~L} / \mathrm{s}$, at TBEnt 1 and TBAlt 3 during groundwater extraction by a submersible pump (Grundfos GmbH, Erkrath, Germany) installed in the well casing a few meters below the groundwater table with a rate of 6.0 and $6.6 \mathrm{~L} / \mathrm{s}$, respectively. Each $\log$ consisted of continuous measurements with data recording every $5-10 \mathrm{~cm}$ starting at least $2 \mathrm{~m}$ above and ending $2 \mathrm{~m}$ below the screened sections or open borehole. Prior to groundwater extraction, baseline flowmeter logs were measured at TBEnt 1 and TBAlt 3 under ambient conditions without pumping. At ArtAlt, a video log (Wiggerich VideoInspektionssysteme, Arnsberg, Germany) was additionally performed in March 2014, which in combination with the results of the flowmeter logging, allowed to visualize the horizons of groundwater inflow.

\section{Depth-specific groundwater sampling}

Groundwater samples for hydrochemical and tritium analysis were taken from the artesian well ArtAlt in July 2014, directly after the flowmeter logging. Groundwater was collected from three different depths $(17.5 \mathrm{~m}, 30.5 \mathrm{~m}, 46.0 \mathrm{~m}$ bgs) to capture the changes caused by inflowing groundwater from the major fractures. The samples were taken from all three depths simultaneously with a flow rate of about $0.1 \mathrm{~L} /$ min using a set of custom-made pneumatically controlled, miniaturized double-valve pumps. For the pneumatic activation of the pumps, nitrogen gas with a purity of $99.999 \%$ was used. Dissolved ions were quantified in the laboratory by ion chromatography (Thermo Scientific Dionex DX-120; Anions: Dionex IonPac A523 analytical column with a Dionex IonPac AG23 guard column; Cations: Dionex IonPac CS12A-5- $\mu \mathrm{m}$ analytical column with a Dionex IonPac CG12A-5- $\mu \mathrm{m}$ guard column; $\mathrm{LOQ}=0.1 \mathrm{mg} / \mathrm{L}$ ).

Tritium was analysed with the ${ }^{3} \mathrm{He}$-ingrowth method (Sültenfuß et al. 2009). Samples of $500 \mathrm{~g}$ of water were degassed and stored for ${ }^{3} \mathrm{He}$ accumulation in dedicated He-free glass bulbs. After a storage period of 2-6 months, ${ }^{3} \mathrm{He}$ was analyzed with the mass spectrometric system at the Bremen Mass spectrometry facility. This method achieves a detection limit of $0.01 \mathrm{TU}$ (tritium unit). The uncertainty is typically less than $3 \%$ for samples of $>1 \mathrm{TU}$.

The concentration $C_{s}$ of an ion (e.g., $\mathrm{NO}_{3}{ }^{-}, \mathrm{SO}_{4}{ }^{2-}$ ) or tritium in the collected water samples from depth $s$ represents a mixture of groundwater from the inflow $Q_{n}$, directly at the sampling depth (with concentration $C_{n}$ ), and the cumulated vertical groundwater flux from other inflow horizons:

$C_{s} Q_{s}=C_{n} Q_{n}+\sum_{i=1}^{n-1} C_{i} Q_{i}$

where $Q_{s}$ is the cumulative groundwater flux corresponding to the value measured by the flowmeter log at depth $s$. The concentrations $C_{i}$ were derived by rearranging Eq. (1) for each inflow horizon $i$ and solving the system of linear equations for the unknown concentrations.

\section{Gamma logging}

Logging of the natural gamma radiation was applied for assessment and assignment of the lithological and stratigraphic setting at the artesian well ArtAlt using a slim gamma probe (Mount Sopris Instruments, Denver, USA). Logging was performed over the entire depth of the well with the smallest possible logging speed of approximately $1.8 \mathrm{~m} / \mathrm{min}$ and a depth resolution of approximately $5 \mathrm{~cm}$. 
For the analysis, four logs were averaged for improving the signal-to-noise ratio.

\section{Modeling approach}

\section{Conceptional setup of geometry and reaction fronts}

Advective transport in the carbonate aquifer is restricted to the fracture network of the carbonate rocks. Due to the small permeability of the carbonate formations, water flow in the matrix is assumed to be very low and is therefore neglected. Access to the electron donors in the rock matrix is provided by slow diffusive exchange between mobile water in the fractures and pore water in the rock matrix. Due to reactions between electron donor-bearing minerals in the rock matrix and electron acceptors $\left(\mathrm{O}_{2}\right.$ or $\left.\mathrm{NO}_{3}{ }^{-}\right)$entering the porous matrix by diffusion, a moving reaction front will develop along the hydraulically active fractures (Sidborn and Neretnieks 2007, 2008). The extent of rock matrix contributing to the reduction capacity of the aquifer is growing with time and increasing electron acceptor/donor ratio. On time scales of decades or at high electron donor concentration, reduction is restricted to a narrow zone around the fractures, which is usually substantially smaller than the total extent of the aquifer (Fig. 2).
In general, the penetration depth $z$ of a solute or a reaction front into the rock matrix after time $t$ can be expressed based on the mean square displacement (e.g., Grathwohl 1998; Sidborn and Neretnieks 2007):

$z=\sqrt{2 D_{\mathrm{a}} \mathrm{t}}=\sqrt{2 D_{\mathrm{e}} \frac{C_{\mathrm{a}}}{C_{\mathrm{d}}} t}$

$D_{\mathrm{e}}=D_{\mathrm{aq}} \frac{\varepsilon}{\tau} \approx D_{\text {aq }} \varepsilon^{2}$

where $D_{\mathrm{a}}$ and $D_{\mathrm{e}}$ are the apparent and effective diffusion coefficients, respectively. The reciprocal of the acceptor/ donor ratio $C_{\mathrm{a}} / C_{\mathrm{d}}$ accounts for retardation of the electron donor depletion front in the rock matrix. $D_{\mathrm{e}}$ is derived from the aqueous diffusion coefficient $D_{\text {aq }}$ by accounting for the porosity $\varepsilon$ and tortuosity $\tau$ of the rock matrix (Rügner et al. 1999; Boving and Grathwohl 2001). After onset of the current hydrological cycle, the oxidation of electron donors by $\mathrm{O}_{2}$ followed by the reduction of natural (nonanthropogenic) $\mathrm{NO}_{3}{ }^{-}$formed a sequence of depletion fronts in the rock matrix along fractures. Due to high concentrations, the recently added anthropogenic $\mathrm{NO}_{3}{ }^{-}$lead to an accelerated penetration of the nitrate depletion front into the matrix as depicted in Fig. 2b. The thickness of the rock matrix contributing to nitrate reduction is considered to reach a maximum

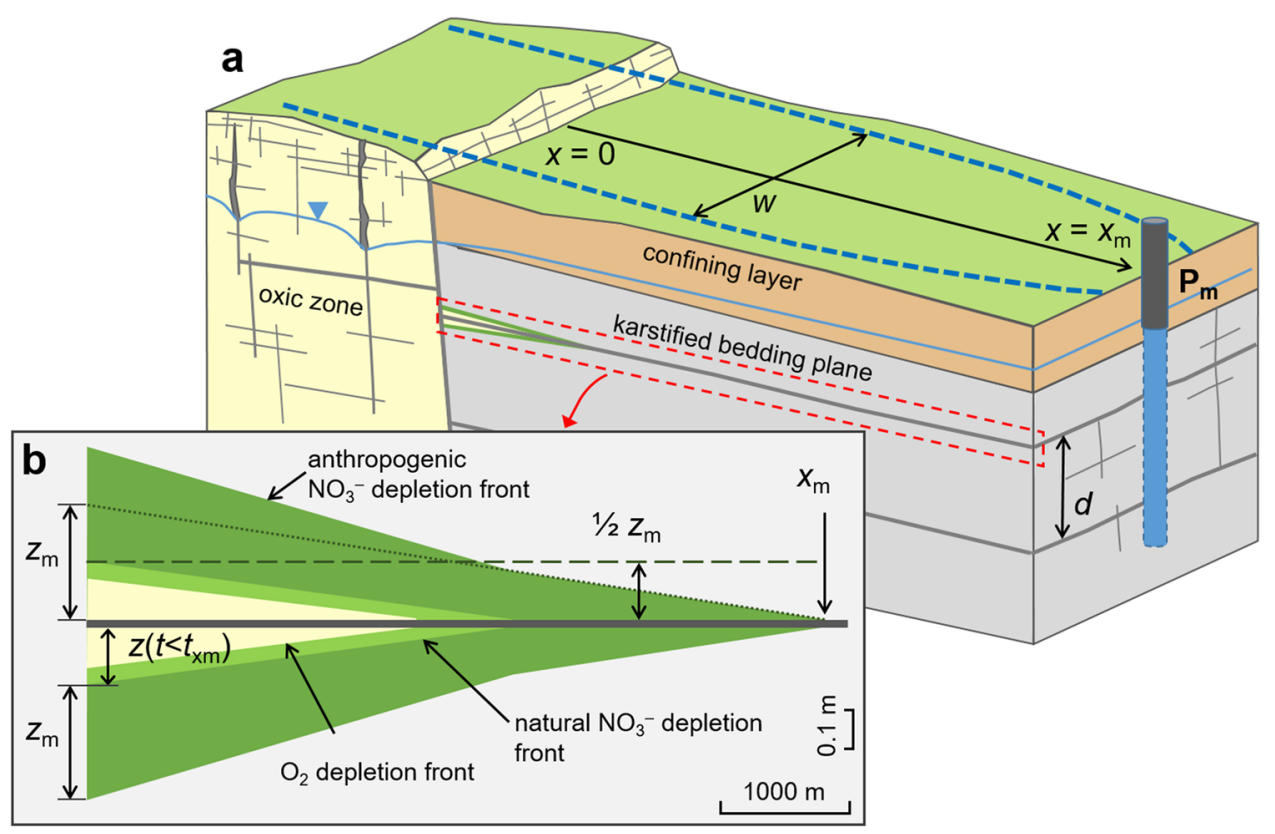

Fig. 2 a Schematic display of a typical section across the oxic and the confined part of the fractured carbonate aquifer. The dashed blue line represents the capture zone of a hypothetical well $\mathrm{P}_{\mathrm{m}}$. b Location of electron donor depletion fronts in the rock matrix along a fracture/ bedding plane as assumed in the electron acceptor/donor balance model (vertical scale exaggerated). The sketch shows the situation when the front has just reached the location $x_{\mathrm{m}}$ of the well. Note that the depths of the fronts within the rock matrix are additive, i.e. the depletion due to reactions of $\mathrm{O}_{2}$ and $\mathrm{NO}_{3}{ }^{-}$only would form a triangular depletion area, as indicated by the dotted line. Note further that the size of this depletion area is $1 / 2 z_{\mathrm{m}} x_{\mathrm{m}}$ 
value $z_{\mathrm{m}}$ at time $t_{\mathrm{xm}}$ when the depletion front along the fracture reaches a hypothetical well $\mathrm{P}_{\mathrm{m}}$ at $x_{\mathrm{m}}$. Given that the reaction front can be approximated by a linear decrease of $z$ with increasing distance along the fracture as shown in Fig. 2b (see also Sidborn and Neretnieks 2007), the total area of $\mathrm{NO}_{3}{ }^{-}$depletion in the rock matrix may be represented by half of the depth $z_{\mathrm{m}}$; hence, the factor $1 / 2$ in Eq. (5). The prolonged exposure of reactive minerals to $\mathrm{O}_{2}$ and natural $\mathrm{NO}_{3}{ }^{-}$since the onset of the current ground water flow regime resulted in the depletion of electron donors in parts of rock matrix along the fractures. The degradation of anthropogenic $\mathrm{NO}_{3}{ }^{-}$leads to the depletion of minerals further inside the rock matrix and is additive to the previous mineral depletion. Correspondingly, the depth of the depletion front $z_{\mathrm{m}}$ in the rock matrix is calculated independently of any previous mineral depletion (see Fig. 2). This approach is justified by the relatively fast nonreactive diffusion of $\mathrm{NO}_{3}{ }^{-}$across the depleted porous matrix with a pore diffusion coefficient of $D_{\mathrm{e}} / \mathcal{E}$ (Grathwohl 1998).

\section{Electron acceptor/donor mole balance}

The nitrate reduction potential of the fractured carbonate aquifer is assessed by quantifying the moles of electron donors in the rock matrix along hydraulically active fractures, which allow the transport of known quantities of the electron acceptors dissolved oxygen $\left(\mathrm{O}_{2}\right)$ and nitrate $\left(\mathrm{NO}_{3}{ }^{-}\right)$. A mole balance is applied to groundwater extracted or discharging naturally from a typical aquifer section forming the capture zone of a hypothetical well $\mathrm{P}_{\mathrm{m}}$ (or other discharge point) as shown in Fig. 2. The number of moles of $\mathrm{NO}_{3}{ }^{-}$(or of any other electron acceptor) $N_{\mathrm{a}}$ that are transformed in the aquifer section over time $t$ can be derived by:

$N_{\mathrm{a}}=C_{\mathrm{a}} Q t$

where $C_{\mathrm{a}}$ is the concentration of $\mathrm{NO}_{3}{ }^{-}$in $\mathrm{mol} / \mathrm{L}$ in the groundwater entering the fractures (nitrate input). The discharge $Q$ (in L/year) constitutes the groundwater flux emerging from the fracture network at $x_{\mathrm{m}}$. Note that in Eq. (4) the nitrate input $C_{\mathrm{a}}$ and discharge $Q$ are assumed to remain constant over time or to represent time averaged values. The nitrate reduction potential protecting the well $\mathrm{P}_{\mathrm{m}}$ is governed by the volumetric molar concentration of electron donor equivalents $C_{\mathrm{d}}$ in mol $\mathrm{NO}_{3}{ }^{-} / \mathrm{L}$, which comprises the concentration $C_{i}$ of all electron donors in the rock matrix next to the effective fractures and the stoichiometric factors $\gamma_{i}$ of each reaction (moles of $\mathrm{NO}_{3}{ }^{-}$that can be reduced by one mole of donor $i$ ): $C_{\mathrm{d}}=\sum C_{i} \gamma_{i}$. The number of moles of electron donor equivalents $N_{\mathrm{d}}$ that is available for nitrate reduction before the nitrate front reaches the well at $\mathrm{P}_{\mathrm{m}}$ can be expressed as:
$N_{\mathrm{d}}=2 C_{\mathrm{d}} w x_{\mathrm{m}} \frac{z_{\mathrm{m}}}{2} n_{\mathrm{f}}$

where $w$ denotes the width of the cross section providing $Q$ (perpendicular to flow but parallel to fracture planes), $x_{\mathrm{m}}$ is the distance (parallel to flow) between the well $\mathrm{P}_{\mathrm{m}}$ and the boundary to the oxic zone at $x=0$ (see Fig. 2), $z_{\mathrm{m}}$ is the penetration depth of the nitrate reduction front into the rock matrix at $x=0$ for the time when the reaction front reaches the well at $\mathrm{P}_{\mathrm{m}}$, and $n_{\mathrm{f}}$ is the number of hydraulically active fractures. The width $w$ of the capture zone of well $\mathrm{P}_{\mathrm{m}}$ is related to discharge $Q$ by Darcy's law:

$Q=A K I=d n_{\mathrm{f}} w K I$

where $A$ is the cross-section of the capture zone of well $\mathrm{P}_{\mathrm{m}}$, $K$ is the mean bulk hydraulic conductivity of the fractured aquifer, $d$ the mean fracture spacing, and $I$ the hydraulic gradient along the capture zone. Under the assumption of a network of (parallel) fractures with laminar flow and a mean effective aperture $b$, the hydraulic conductivity of the fractured aquifer is given by:

$K=\frac{g}{12 \vartheta} \frac{b^{3}}{d}$

where $g$ is the gravitational acceleration and $\vartheta$ the kinematic viscosity of water at $10^{\circ} \mathrm{C}$.

Assuming a quasi-steady state where the nitrate input concentration, groundwater discharge rate, and groundwater flow paths stay constant over the considered time $t$, the remaining fraction of protection potential $r_{\mathrm{PP}}=1-N_{\mathrm{a}} / N_{\mathrm{d}}$ along all groundwater flow paths contributing to $Q$ can be quantified by combining Eqs. (4-6):

$r_{\mathrm{PP}}=1-\frac{C_{\mathrm{a}}}{C_{\mathrm{d}}} \frac{Q t}{n_{\mathrm{f}} w x_{\mathrm{m}} z_{\mathrm{m}}}=1-\frac{C_{\mathrm{a}}}{C_{\mathrm{d}}} \frac{d K I t}{x_{\mathrm{m}} z_{\mathrm{m}}}$

By definition, the well protection potential is depleted (i.e. nitrate concentration $\geq 0$ ) when the reaction front has arrived at $x_{\mathrm{m}}$ after time $t=t_{\mathrm{xm}}$. For this situation, $r_{\mathrm{PP}}$ in Eq. (8) becomes zero and thus can be used to determine $t_{\mathrm{xm}}$ after inserting Eqs. (2) and (3) for $z_{\mathrm{m}}=z\left(t_{\mathrm{xm}}\right)$ into Eq. (8):

$t_{\mathrm{xm}}=2 D_{\text {aq }} \frac{C_{\mathrm{d}}}{C_{\mathrm{a}}}\left(\frac{\varepsilon x_{\mathrm{m}}}{d K I}\right)^{2}$

Inserting this expression into Eq. (2), the average penetration depth of the reaction front $z_{\mathrm{m}}$ can also be written as:

$z_{\mathrm{m}}=\frac{2 x_{\mathrm{m}} \varepsilon^{2} D_{\mathrm{aq}}}{d K I}$

Now $z_{\mathrm{m}}$ is independent of $C_{\mathrm{a}} / C_{\mathrm{d}}$ for a given value of $x_{\mathrm{m}}$. Provided that the different fractures contributing to discharge $Q$ can be represented by "averaged fractures" 
with an effective aperture and flow velocity, $z_{\mathrm{m}}$ constitutes a representative mean of the considered aquifer section. Note that the derivation of Eqs. (9) and (10) is based on the assumption that the reaction with minerals is instantaneous and that the $\mathrm{NO}_{3}{ }^{-}$concentration in the pore water of the rock matrix is much smaller than the concentration of electron donors in the rock. As such it represents an optimal case for nitrate reduction. Inserting Eq. (10) into Eq. (8), the remaining well protection potential $r_{\mathrm{PP}}$ becomes:

$r_{\mathrm{PP}}=1-\frac{C_{\mathrm{a}}}{C_{\mathrm{d}}}\left(\frac{d K I}{\varepsilon x_{\mathrm{m}}}\right)^{2} \frac{t}{2 D_{\mathrm{aq}}}$

\section{Parameter assignment and model scenarios}

The parameters required to calculate $r_{\mathrm{PP}}$ can usually be obtained from basic hydrogeological studies or monitoring programs. In this work, $r_{\mathrm{PP}}$ was determined for the aquifer matrix of a typical well catchment situated in the confined part of the aquifer. Modeling was performed for the geological and geochemical conditions determined for three of the four investigated facies (aggregating shoal and backshoal facies). In addition, for each facies two different nitrate input scenarios were considered: (1) low natural nitrate concentrations $(\sim 1.0 \mathrm{mg} / \mathrm{L})$ that presumably prevailed during onset of the current groundwater flow regime, and (2) high anthropogenic nitrate concentrations $(>10 \mathrm{mg} / \mathrm{L})$ that started about 60 years ago. Regional groundwater flow is assumed to take place mainly in horizontal fractures or bedding planes. A spacing of hydraulically active fractures/ bedding planes $d$ of $10 \mathrm{~m}$ was used, corresponding to a mean value determined from flowmeter logs at the three studied wells. Hydraulic conductivity of the fractured aquifer was set to $2.0 \times 10^{-5} \mathrm{~m} / \mathrm{s}$, which is in the upper range of values reported for the confined part of the aquifer (D'Affonseca et al. 2020). The length of the effective bedding planes $x_{\mathrm{m}}$ was taken to be about $5,000 \mathrm{~m}$ corresponding to the average distance of the production wells from the start of the confining layers preventing oxygen replenishment along karstic features. The hydraulic gradient $I$ of $1.0 \%$ was derived from water table contours (D'Affonseca et al. 2020).

The depth of the rock matrix potentially contributing to nitrate reduction was determined using Eq. (10). The effective diffusion coefficient $D_{\mathrm{e}}$ has been estimated as $0.004-1.0 \times 10^{-10} \mathrm{~m}^{2} / \mathrm{s}$ for a nitrate diffusion coefficient $D_{\text {aq }}$ of $1.5 \times 10^{-9} \mathrm{~m}^{2} / \mathrm{s}$ (in pure water at $10^{\circ} \mathrm{C}$; e.g., Picioreanu et al. 1997) and mean porosities $\varepsilon$ of 23,5 , and $1 \%$ of the shoal/backshoal, tempestite, and basinal facies, respectively. Similar values for $D_{\mathrm{e}}$ were reported by Hill (1984) for a chalk aquifer in the UK. The concentration of electron donor equivalents $C_{\mathrm{d}}$ was determined from measured concentrations of reactive minerals by assuming that nitrate reduction is coupled to the oxidation of reduced iron Fe(II) and sulfur $\mathrm{S}(-\mathrm{I})$ contained in pyrite $\left(\mathrm{FeS}_{2}\right)$ and iron-rich dolomites $\mathrm{Ca}(\mathrm{Fe}, \mathrm{Mg})\left(\mathrm{CO}_{3}\right)_{2}$ according to the following reactions (Straub et al. 1996; Appelo and Postma 2005):

$5 \mathrm{FeS}_{2}+14 \mathrm{NO}_{3}+4 \mathrm{H}^{+} \rightarrow 10 \mathrm{SO}_{4}+7 \mathrm{~N}_{2}+5 \mathrm{Fe}^{2+}+2 \mathrm{H}_{2} \mathrm{O}$

$10 \mathrm{Fe}^{2+}+2 \mathrm{NO}_{3}+24 \mathrm{H}_{2} \mathrm{O} \rightarrow 10 \mathrm{Fe}(\mathrm{OH})_{3}+\mathrm{N}_{2}+18 \mathrm{H}^{+}$

Based on the stoichiometry of these reactions, $C_{\mathrm{d}}$ in $\mathrm{mol} / \mathrm{L}$ can be calculated from the average abundance of reactive minerals $C_{\mathrm{pyr}}$ and $C_{\mathrm{dol}}$ (in wt.\%) as follows:

$C_{\mathrm{d}}=\left(C_{\mathrm{Fe}(\mathrm{II})} \cdot \frac{1}{5}+C_{\mathrm{S}(-\mathrm{I})} \cdot \frac{7}{5}\right) \rho_{\mathrm{r}}(1-\varepsilon)$

with:

$C_{\mathrm{Fe}(\mathrm{II})}=\left(C_{\mathrm{pyr}} \cdot 0.465+C_{\mathrm{dol}} \cdot 0.059\right) \cdot \frac{1000}{55.845}$

$C_{\mathrm{S}(-\mathrm{I})}=\left(C_{\mathrm{pyr}} \cdot 0.535\right) \cdot \frac{1000}{32.065}$

where $C_{\mathrm{Fe}(\mathrm{II})}$ and $C_{\mathrm{S}(-\mathrm{I})}$ are the molar concentrations (in $\mathrm{mol} / \mathrm{g}$ ) of reduced iron and sulfur, respectively. The mean density of the carbonate minerals was set to $\rho_{\mathrm{r}}=2.7 \mathrm{~g} / \mathrm{cm}^{3}$.

\section{Results and discussion}

\section{Type, occurrence, and characterization of reactive minerals}

Concentrations of organic carbon $f_{\mathrm{oc}}$ in the Upper Muschelkalk rock matrix are rather low with values in the range of 0.04-0.31 wt.\% (three samples from the Herrenberg quarry) and 0.02-0.18 wt.\% (six samples from the Mötzingen quarry). The mean $f_{\text {oc }}$ value of $0.12 \mathrm{wt} . \%$ is in good agreement with data from Kleineidam et al. (1999a, b), who reported $f_{\text {oc }}$ values in Muschelkalk rock fragments from the same region in the range of $0.03-0.09 \mathrm{wt} . \%$. They also showed that, due to burial history, the organic matter in the carbonates of the Muschelkalk is mainly composed of kerogen (inert amorphous organic matter) and of limited bioavailability.

Results from pyrite $\left(\mathrm{FeS}_{2}\right)$ quantification via sulfur measurements performed in four rock samples from the Herrenberg quarry indicate that considerable amounts of pyrite are present in the rock matrix. The concentration ranges between 0.6 and $1.6 \mathrm{wt} . \%$. Bivalent iron $\left(\mathrm{Fe}^{2+}\right)$ might also be present as a substitute of $\mathrm{Mg}^{2+}$ in the crystal lattice of dolomites, particularly in the Rottweil Formation (Schauer and Aigner 1997). However, iron concentrations 
were too low to be quantified (Fig. S2 of ESM), suggesting that these dolomites may not significantly contribute as electron donors. In addition to pyrite, marcasite, a metastable form of $\mathrm{FeS}_{2}$, and saddle dolomite, an ironbearing dolomite characterized by a higher $\mathrm{Fe}^{2+}$ content, are considered to constitute the main reactive minerals in the Upper Muschelkalk of the study area (Fig. 3).

Pyrite occurs as finely distributed crystals of $1-40 \mu \mathrm{m}$ in size, as framboidal pyrite, in fecal pellets, or along $\mathrm{C}$-rich layers in shell fragments. The subhedral to euhedral, mostly uncorroded pyrite minerals are precipitated in anoxic to suboxic marine sediments at the water-sediment interface and during shallow burial (Berner 1985; Fig. 3g).
Marcasite, an orthorhombic metastable form of $\mathrm{FeS}_{2}$, often is present as aggregates and can be found together with pyrite in fractures and veins indicating a post-sedimentary transport of iron along tectonic pathways.

Saddle dolomite is an iron-bearing dolomite with a considerable $\mathrm{Fe}^{2+}$ content (1.7-2.6 wt.\% as obtained from EDX analyses; Fig. S2 of ESM). In thin sections, saddle dolomite shows the typical oscillatory extinction in x-polarized light (Fig. 3c). Characteristic are large mm-sized cloudy crystals, curved cleavage plains, and crystal surfaces often with limonite staining. Coatings with limonite can also occur around the edges of the vugs (Köhrer et al. 2010). Saddle dolomite forms from hypersaline fluids at elevated temperatures from $60^{\circ}$ up to $180^{\circ} \mathrm{C}$ (Radke and Mathis 1980; Spötl and
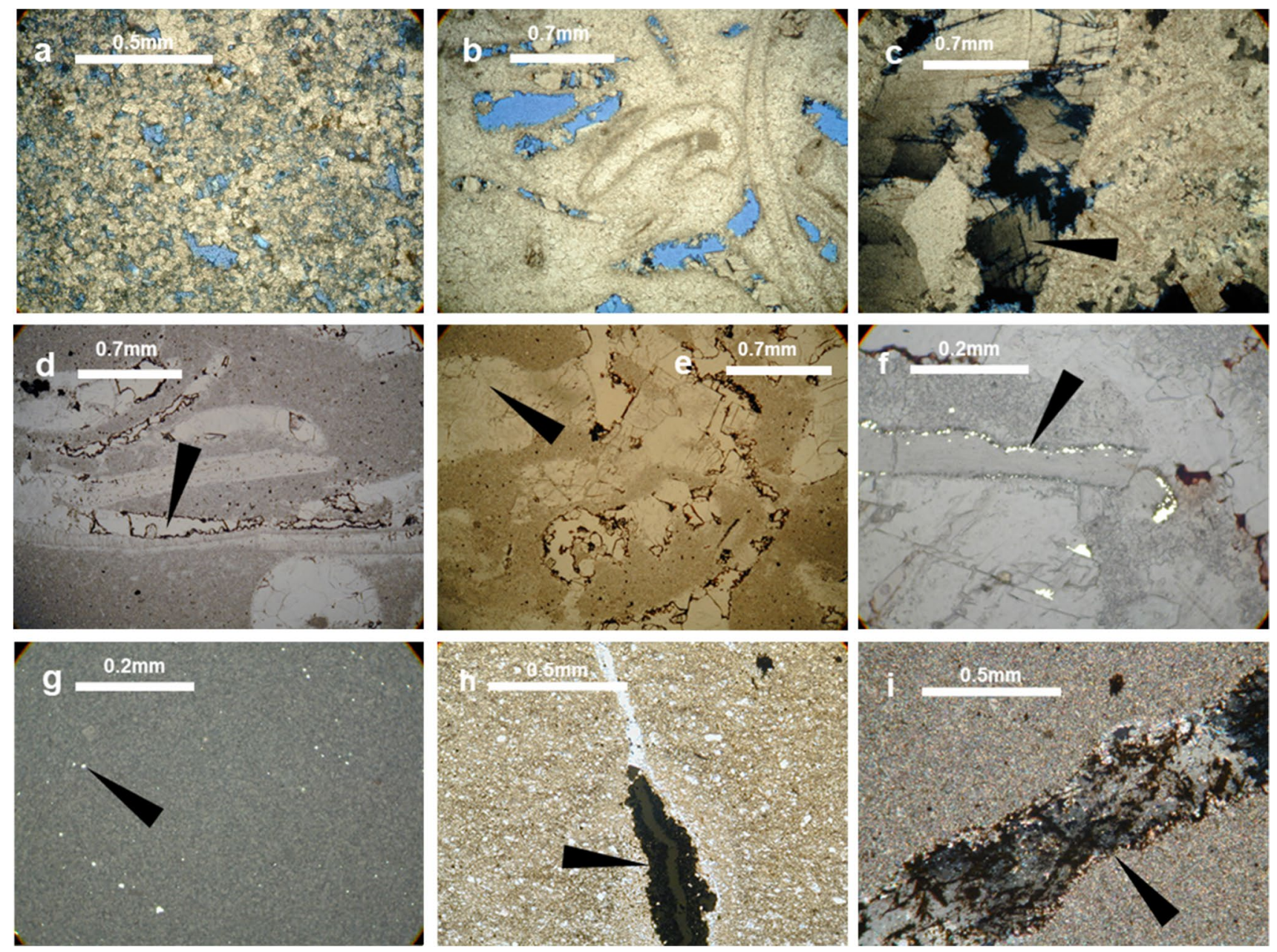

Fig. 3 Thin-section photomicrographs of a Backshoal facies: dolomudstone with intercrystalline porosity (blue), Herrenberg quarry (transmitted light). b Shoal facies: bioclastic grainstone with vuggy porosity (blue), Mötzingen quarry (transmitted light). c Shoal facies: saddle dolomite from Mötzingen quarry (transmitted light, crossed polarized light). d Tempestite facies: bioclastic pack- to wackestone with shell debris and crinoid in micritic matrix and brown limonite rims in vuggy porosity, drilling core Reusten (transmitted light). e Tempestite facies with saddle dolomite from drill core Reusten in plane polarized light. f Tempestite facies: thin layer of syn-depositional pyrite (appearing as white-yellow spots) lining rim of shell component from drill core Reusten (reflected light, oil). g Basinal facies with syn-depositional pyrite appearing as white-yellow spots, from Mötzingen quarry (reflected light, oil). h Basinal facies with post-depositional pyrite/marcasite in fracture, from drill core Reusten (transmitted light). i Basinal facies with saddle dolomite as fracture fill from Mötzingen quarry (crossed polarized light) 
Pitman 1998; Gregg and Shelton 1990; Davies and Smith 2006), which can be caused by burial diagenesis, a higher geothermal gradient, or by upward movement of hydrothermal fluids (Machel and Lonnee 2002). In the study area, only temperatures of about $60^{\circ} \mathrm{C}$ were reached during burial by the maximal 1,000 -m-thick sedimentary overload of the Keuper and Jurassic formations (Geyer and Gwinner 2011) at an expected geothermal gradient of $30-40{ }^{\circ} \mathrm{C} / 1,000 \mathrm{~m}$. As already suggested by Zeeh and Geng (2001), it has therefore to be assumed that in the region "Oberes Gäu" percolating hydrothermal fluids supported the precipitation of the saddle dolomite as well as the pyrite/marcasite precipitation in fractures and veins of the Upper Muschelkalk.

\section{Major facies types and distribution of reactive minerals}

The occurrence and type of reactive minerals varies across different facies types. In order to describe the reactivity of the Upper Muschelkalk with respect to nitrate reduction, four lithological and geochemical distinct facies types were considered. By regrouping and merging of the original 21 facies types (Warnecke and Aigner 2019), the following four facies types cover the almost complete sequence of the Upper Muschelkalk in the study area: (1) backshoal facies, (2) shoal facies, (3) tempestite facies, and (4) basinal facies. These facies types differ mainly by the depositional environment but also by porosity and type and content of Fe(II) minerals (Table 1).

\section{Backshoal facies}

The low-energy backshoal facies (Fig. 3a) is represented by the dolomitic mud- to packstones of the Rottweil Formation, which were deposited in a peritidal and lagoonal setting.
Porosity is high due to intercrystalline pores. Analysis of thin sections from the study area revealed a porosity of $15-28 \%$ for this facies type. Values from previous published studies range from 0.1 to 32\% (Schauer and Aigner 1997; Köhrer et al. 2010). Pyrite was observed in thin sections in amounts of up to $1 \mathrm{wt} . \%$ as small anhedral pyrite crystals in the matrix. Saddle dolomite sometimes is present in pore spaces originating from bioturbation or anhydride solution and in fissures and fractures in an amount of up to $1 \mathrm{wt} . \%$. Zeeh and Geng (2001) give iron content values in the Rottweil Formation of 0.6-0.7 wt.\%.

\section{Shoal facies}

Towards the basin follow the bioclastic dolomites and limestones of the high energy shoal facies (Fig. 3b, c). Porosity is high due to interparticle and moldic pores. Visual inspection of thin sections suggests a porosity of $15-30 \%$. Previously published studies give porosity values ranging from 4 to $30 \%$ (Braun 2003; Kostic and Aigner 2004; Köhrer et al. 2010; Palermo et al. 2012). Pyrite was observed in thin sections in amounts of 1-2 wt.\% including early diagenetic pyrite as well as late diagenetic pyrite associated with vuggy and moldic pore spaces. Saddle dolomite is present in fractures and as pore fillings in amounts of up to $2 \mathrm{wt} . \%$.

\section{Tempestite facies}

The poorly sorted to graded bioclastic packstones to wackestones of the tempestite facies in the studied rock samples (Fig. 3d-f) are sedimented as proximal to distal storm deposits of the mid to deeper ramp (Aigner 1985; Köhrer et al. 2010). Thin-section examination suggests a porosity value of $0.5-10 \%$. Porosity values from previous published studies range from 0.5 to 20\% (Braun 2003; Kostic and Aigner

Table 1 Typical ranges of porosity, pore size, abundance of pyrite (Pyr) and saddle dolomite (sDol) as well as grain sizes of reactive minerals for the main facies types of the Middle Triassic carbonate rocks in the study area

\begin{tabular}{|c|c|c|c|c|c|c|c|}
\hline Facies type & Sedimentary environment & $\begin{array}{l}\text { Abundance } \\
\text { of facies }^{\mathrm{a}} \\
(\%)\end{array}$ & $\begin{array}{l}\text { Porosity } \\
(\%)\end{array}$ & $\begin{array}{l}\text { Pore size } \\
(\mu \mathrm{m})\end{array}$ & $\begin{array}{l}\text { Pyr } \\
\text { (wt.\%) }\end{array}$ & $\begin{array}{l}\text { sDol } \\
\text { (wt.\%) }\end{array}$ & $\begin{array}{l}\text { Size of minerals } \\
(\mu \mathrm{m})\end{array}$ \\
\hline Backshoal facies & Coastal to lagoonal setting & 11 & $15-28$ & $<1-280$ & Up to 1.0 & $<0.1-1$ & n.d. \\
\hline Shoal facies & Shoal body & $2^{\mathrm{c}}$ & $15-30$ & $<1-1,700$ & $1.0-2.0$ & $<0.1-2$ & $\begin{array}{l}\text { sDol: } \\
<100-1500\end{array}$ \\
\hline Tempestite facies & Storm deposits of the mid to deeper ramp & 12 & $0.5-10$ & $<1-1,500$ & $1.0-2.0$ & $<0.1-2$ & $\begin{array}{l}\text { sDol: } \\
<100-1280\end{array}$ \\
\hline Basinal facies & Basinal setting below storm wave base & 75 & $0.5-5.0$ & n.d. & up to 4.0 & $<0.1-0.5$ & $\begin{array}{l}\text { Pyr: } \\
<1-40\end{array}$ \\
\hline
\end{tabular}

n.d. not detected

${ }^{\mathrm{a}}$ Based on data from quarry Mötzingen.

${ }^{\mathrm{b}}$ Sizes below the lower bound could not be quantified

${ }^{\mathrm{c}}$ In this study, shoal facies only refers to high-porosity horizons 
2004; Köhrer et al. 2010). Pyrite concentrations of 1-2 wt.\% were observed in the tempestite facies in reducing microenvironments as early diagenetic pyrite and as pyrite and marcasite in fractures. Saddle dolomite occurs in pore space and in fissures in an amount of 0-2 wt.\%.

\section{Basinal facies}

The mud-dominated sediments of the basinal facies (Fig. 3g-i) are suspension deposits of the low-energy deeper ramp below the storm wave base. Porosity is low with values of $0.5-5 \%$, which corresponds to ranges from previous published studies (Braun 2003; Kostic and Aigner 2004). However, values in the very low range could not be accurately determined from thin sections. Pyrite occurs as early diagenetic, finely dispersed unaltered subhedral to euhedral crystals of $1-40 \mu \mathrm{m}$ in size (up to $4 \mathrm{wt} . \%$ ) or in fractures (Fig. 3g, h). Saddle dolomite is rare but can occur in fissures and fractures (Fig. 3i) and rarely in cavities from bioturbation in an amount of up to $0.5 \mathrm{wt} . \%$.

\section{Evidence of reactivity}

In rock fragments and thin sections of the shoal and the tempestite facies, alteration of the saddle dolomite resulted in dark brown limonite rims in the moulds and vugs due to oxidation processes. In general, fresh limestone rock fragments of the Upper Muschelkalk show a medium-todark-grey colour, which partly turns to light brown at the surfaces due to weathering. This is believed to be caused by ferric oxyhydroxide accumulating at rims or along fissures. Brownish weathering surfaces are described in other studies, e.g., from the Jurassic Lincolnshire limestone by Baker et al. (2012), and usually attributed to the oxidation of pyrite. Sulfide is converted to aqueous sulfate and removed from the rock matrix whilst ferrous iron is converted to solid ferric oxyhydroxide phases (Baker et al. 2012). On the fracture surfaces a pyrite-depleted brownish high-porosity coating will develop. The contribution of denitrification to the oxidation of pyrite is difficult to assess and the observed coatings most likely resulted from exposure to atmospheric or dissolved oxygen during the present and past hydrological cycles.

\section{Groundwater flow paths with advective nitrate transport}

Depth profiles of groundwater inflow and nitrate concentrations at the artesian well ArtAlt, located in the confined part of the aquifer, indicate that only a few fractures significantly contribute to groundwater flow (Fig. 4b). Based on flowmeter logging, four major active fractures were identified (Table 2), which under artesian conditions produced a natural groundwater discharge of 5-50 L/s (2014-2019). Fracture spacing ranges from about 3-16 $\mathrm{m}$ with a mean value of $10 \mathrm{~m}$.

The video-logging revealed that depths of high inflow correspond with horizontal, partly karstified open bedding planes (Fig. 4c). These "fractures" most probably evolved above thin interbeddings of low-permeability marl or clay layers within the carbonate rocks. This is confirmed by a gamma profile of the borehole at ArtAlt. A correlation with the gamma profile measured at the quarry in Mötzingen (Köhrer et al. 2010; Fig. 5) indicates that the two uppermost flow paths are located within the dolomite rocks of the Rottweil Formation mainly consisting of high-porosity backshoal facies.

Besides the four active bedding planes, the video logging shows ten additional open bedding planes, which did not produce a clear signal in the flowmeter logs and apparently do not contribute (or only to a minor extent) to groundwater inflows. According to the gamma profile, most of these structures are also associated with bedding planes of carbonate rock overlying clay horizons, as indicated by peaks in gamma counting rates near the bottom of the fractures. However, the data at ArtAlt do not provide evidence that the active bedding planes below the top of the dolomite rocks, including the two lower flow paths, have contact with highporosity tempestite or low-porosity micritic (basinal) facies.

Nitrate concentrations were low $(1-3 \mathrm{mg} / \mathrm{L})$ for all groundwater inflows (see Table 2), suggesting that conditions for nitrate retardation by reactive processes and matrix diffusion are similar at all groundwater flow paths. Moreover, the rather constant sulfate concentrations (agreement within analytical uncertainties) in all sampled groundwater inflows indicate that nitrate reduction is coupled to oxidation of a similar amount (or absence) of pyrite along the different flow horizons. Tritium concentrations between 3 and $6 \mathrm{TU}$ confirm that most of the groundwater extracted from the well ArtAlt is younger than 60 years. The lower tritium content in the upper flow horizon could be due to the location of the bedding plane in the high-porosity backshoal facies intensifying loss of tritium because of matrix diffusion.

The findings in ArtAlt with respect to number and properties of flow paths as well as their position within the Upper Muschelkalk were confirmed at two other locations (production wells TBAlt3, TBEnt1) at about 1.5 and $5.5 \mathrm{~km}$ distance from ArtAlt (Fig. 1). In both wells three to four active horizontal flow paths were identified by the flowmeter logging (Figs. S3 and S4 of ESM). Main groundwater inflow again was observed in or close to the high-porosity dolomites of the backshoal facies at the top of the Upper Muschelkalk (Rottweil Formation). These findings suggest that a few partly karstified bedding planes control horizontal flow in the Muschelkalk aquifer at a regional scale. Similar primary flow and transport along major horizontal fractures was 

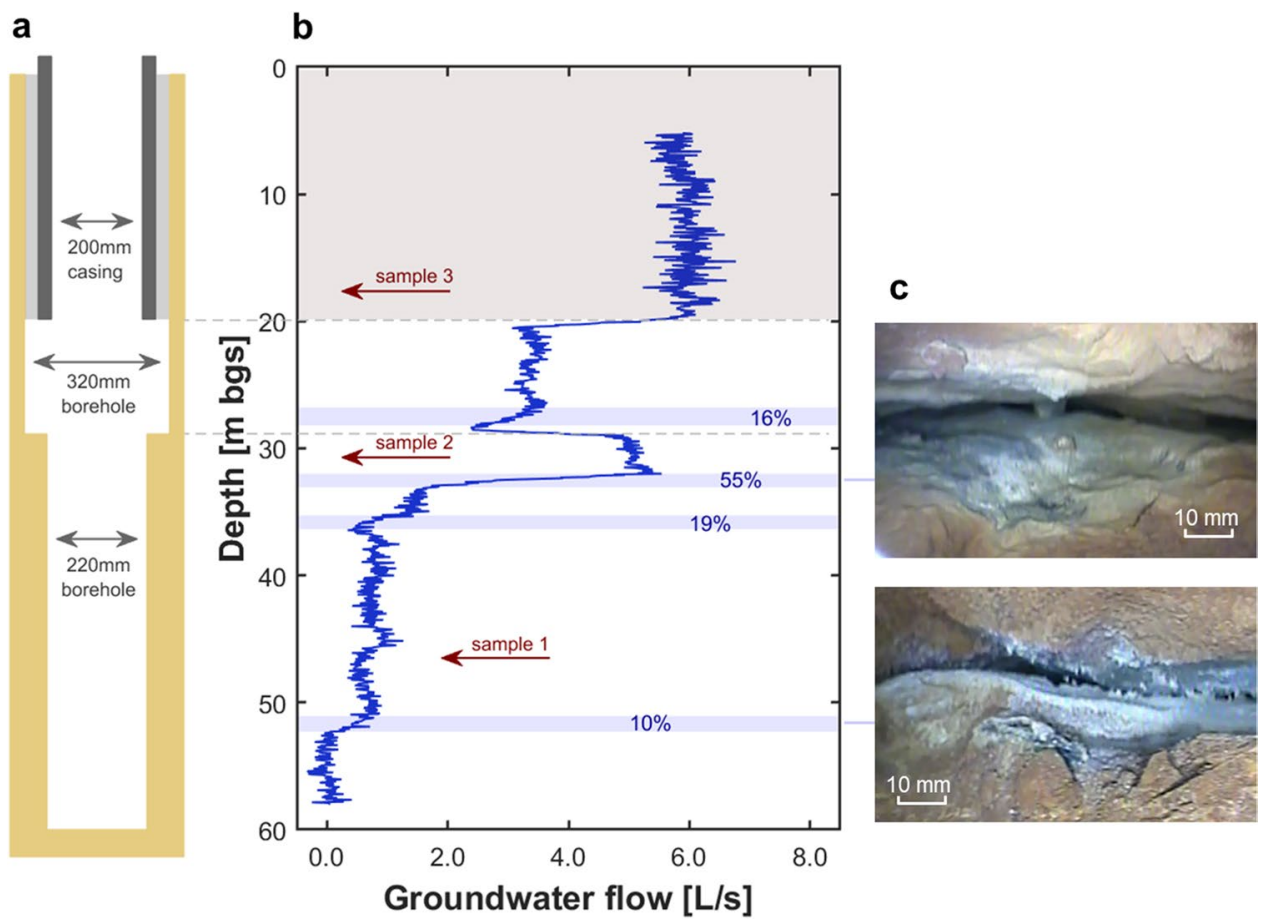

Fig. 4 a Schematic borehole profile of the artesian well ArtAlt. b Flowmeter log at ArtAlt at natural outflow conditions. Zones of significant groundwater inflow are characterized by steep increases in (vertical) groundwater flux and indicated by blue-shaded areas. The percentages represent the relative increase of the flow rate in relation to the total outflow of about $6 \mathrm{~L} / \mathrm{s}$. Variability of the baseline limits the detection of inflows with a contribution of $>5 \%$. The sharp

drop at $28.5 \mathrm{~m}$ as well as the sharp increase in vertical flux at $20 \mathrm{~m}$ (dashed lines) are solely caused by changes in borehole diameter at these depths. Red arrows indicate the depths where three groundwater samples for chemical analyses were taken directly after flowmeter logging. $\mathbf{c}$ Pictures of the fractures at $26.5-28.0 \mathrm{~m}$ and $32.0-33.5 \mathrm{~m}$ bgs taken from the video log
Table 2 Summary of vertical fluxes representing groundwater inflow $Q_{\text {in }}$, relative contribution of fractures $f_{\text {in }}$, and concentrations of nitrate $\left(\mathrm{NO}_{3}{ }^{-}\right)$, sulfate $\left(\mathrm{SO}_{4}^{-}\right)$, and tritium in water samples or calculated for the individual groundwater inflows using Eq. (1) at different depths of the artesian well ArtAlt

\begin{tabular}{llllllll}
\hline $\begin{array}{l}\text { Depth } \\
{[\mathrm{m} \text { bgs }]}\end{array}$ & Type & Facies & $\begin{array}{l}Q_{\text {in }} \\
{[\mathrm{L} / \mathrm{s}]}\end{array}$ & $\begin{array}{l}f_{\text {in }} \\
{[\%]}\end{array}$ & $\begin{array}{l}\mathrm{NO}_{3} \\
{[\mathrm{mg} / \mathrm{L}]}\end{array}$ & $\begin{array}{l}\mathrm{SO}_{4} \\
{[\mathrm{mg} / \mathrm{L}]}\end{array}$ & $\begin{array}{l}\text { Tritium } \\
{[\mathrm{TU}]}\end{array}$ \\
\hline 17.5 & Sample 3 & - & - & - & $2.2 \pm 0.1$ & $93 \pm 8$ & $5.4 \pm 0.2$ \\
$26.5-28.0$ & Inflow 4 & SHF/BSF & 0.96 & 16.0 & $2.7 \pm 1.2$ & $91 \pm 24$ & $3.2 \pm 1.0$ \\
30.5 & Sample 2 & - & - & - & $2.0 \pm 0.1$ & $93 \pm 8$ & $5.8 \pm 0.2$ \\
$32.0-33.5$ & Inflow 3 & SHF/BSF & 3.33 & 55.5 & $2.2 \pm 0.2$ & $94 \pm 12$ & $5.8 \pm 0.3$ \\
$34.5-36.0$ & Inflow 2 & SHF/BSF/BAF & 1.11 & 18.5 & & & \\
46.0 & Sample 1 & - & - & - & $1.2 \pm 0.1$ & $89 \pm 8$ & $5.5 \pm 0.2$ \\
$51.0-52.0$ & Inflow 1 & BAF/TEF & 0.61 & 10.1 & $1.2 \pm 0.1$ & $89 \pm 8$ & $5.5 \pm 0.2$ \\
\hline
\end{tabular}

Given errors are due to analytical uncertainties and uncertainties resulting from the mixing calculations $S H F$ shoal facies, $B S H$ backshoal facies, $T E F$ tempestite facies, $B A F$ basinal facies inferred from tracer tests and flow logs in a limestone aquifer in Denmark (Mosthaf et al. 2018). Although no vertical fractures were observed at the well, such fractures, when roughly aligned with the general flow direction, may additionally contribute to regional groundwater flow. Moreover, due to the tectonic block structure at the study site (D'Affonseca et al. 2020), the horizontal flow is possibly intercepted on the $1-10-\mathrm{km}$ scale by vertical flow and mixing at fault zones with significant vertical displacements.

\section{Zones of high nitrate turnover in the aquifer}

While oxic conditions usually prevail in the uncovered part of karstic or fractured groundwater systems, conditions favourable for denitrification (e.g., low dissolved oxygen) are restricted to the anoxic zone, which is often situated within the confined parts of an aquifer (Rivett et al. 2007; Henson et al. 2019). This is also the case at the study site where high concentrations of dissolved oxygen (3-9 mg/L) and 
Fig. 5 a Facies distribution at Mötzingen quarry (lower part not shown here); b Gamma $\log$ at Mötzingen quarry; and c Gamma log at groundwater well ArtAlt. Indicator clay horizons $(\mathrm{CH})$ are shown as green lines for orientation. Blue bars indicate the locations of the observed groundwater inflows at ArtAlt. The depth scale is related to the boundary between Upper Muschelkalk (mo) and Lower Keuper (ku). The Mötzingen data were modified after Köhrer et al. (2010)

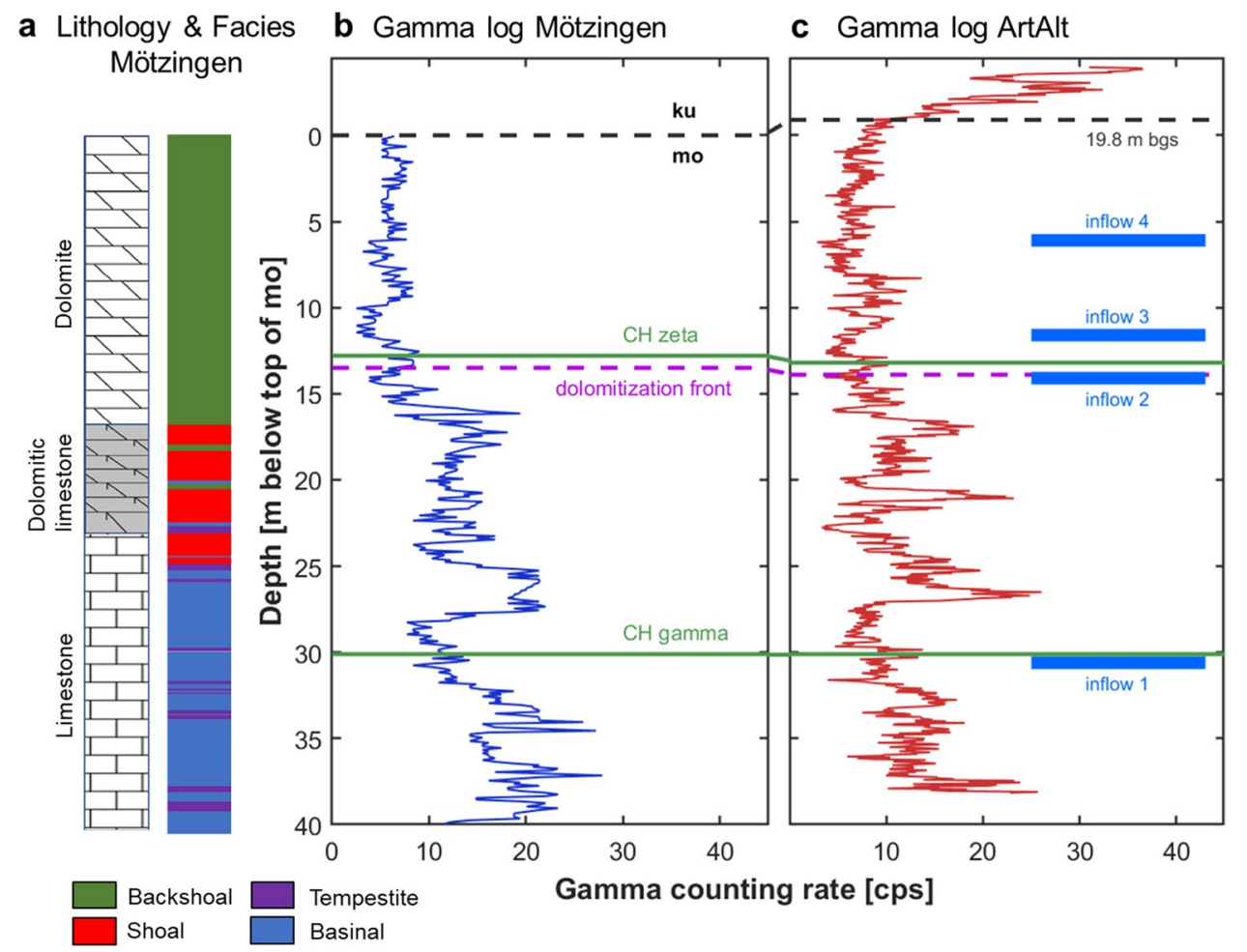

of nitrate (up to $60 \mathrm{mg} / \mathrm{L}$ ) were measured in groundwater samples from the unconfined part of the Muschelkalk aquifer (Visser et al. 2021). Although Visser et al. (2021) found evidence for potential denitrification in niches where (near) anoxic conditions might develop, e.g., beyond the $\mathrm{O}_{2}$ depletion front in the pore matrix along fractures of the phreatic zone or epikarst, a strong decline in groundwater $\mathrm{O}_{2}$ and $\mathrm{NO}_{3}{ }^{-}$concentrations to values close to the detection limit were only found in the confined part of the aquifer (e.g., well ArtAlt). In this part, the replenishment of oxygen due to fast transport along karstic features or vertical fractures across the vadose zone is prevented by the overlying sediments.

High absolute nitrate turnover rates can be expected to occur at those locations where flow in fractures coincides with high abundance of reactive minerals in the rock matrix. Most likely, ferrous iron and reduced sulfur-bearing minerals in the rock matrix (Table 1) are the main electron donors in the carbonate aquifer. Particularly, the divalent iron minerals pyrite/marcasite and saddle dolomite provide a considerable electron donor capacity for nitrate reduction. Therefore, zones of oxygen consumption and subsequent nitrate reduction in the fractured aquifer are attributed to the occurrence and spatial distribution of these minerals, which can be found (1) in the porous backshoal, shoal and tempestite facies, where the saddle dolomite can be dissolved and the released $\mathrm{Fe}$ (II) is subsequently oxidized; the occurrence of these reactions is documented by the limonite rims in vuggy and moldic pore spaces, (2) along fractures filled with post-sedimentary saddle dolomite and pyrite/marcasite, precipitated from ascending hydrothermal fluids, and (3) in the micritic basinal carbonates along fractures and bedding planes, where exposed crystals of syn-sedimentary pyrite can be oxidized to limonite, while pyrite in the central parts of the rock matrix remains unaltered (Baker et al. 2012).

For turnover processes to take place, the reactive minerals are assumed to come into contact with $\mathrm{O}_{2}$ or $\mathrm{NO}_{3}{ }^{-}$, which are transported with groundwater along the horizontal, karstified bedding planes or vertical fractures in the general flow direction. High diffusive fluxes and therefore high nitrate turnover due to a higher effective diffusion constant in Eqs. (2) and (3) can be expected for the high-porosity shoal and backshoal facies, which were found to host the largest part of groundwater flow at the investigated wells in the confined part of the aquifer. However, due to uncertain flow paths between the recharge zone and the studied wells, fractures or bedding planes passing other facies types might contribute substantially to $\mathrm{O}_{2}$ and $\mathrm{NO}_{3}{ }^{-}$depletion, particularly if associated with $\mathrm{Fe}(\mathrm{II})$-rich hydrothermal precipitates near fault zones.

\section{Remaining nitrate reduction potential of the aquifer}

The temporal development of the aquifer's potential to protect wells against nitrate was calculated for the capture zone of a hypothetical water supply well in the confined part of the aquifer, $5 \mathrm{~km}$ distant from the uncovered oxic part (Fig. 2). To this end, Eq. (11) was applied with measured porosities and concentrations of pyrite and saddle dolomite 
of each facies type and a fracture spacing $d=10 \mathrm{~m}$ observed at the investigated wells. In Fig. 6, the remaining well-protective nitrate reduction potential $r_{\mathrm{PP}}$ of each facies is shown for two nitrate input scenarios: "long-term ( 100,000 years) natural background" and "short-term ( 100 years) anthropogenic input". The simulations show that the time required to deplete the nitrate reduction capacity strongly depends on the porosity of the facies constituting the rock matrix. By contrast, the variation of reactive mineral abundances between the facies is small (Table 1) and therefore only of minor importance for the differences in $r_{\mathrm{PP}}$. For $\mathrm{NO}_{3}{ }^{-}$background concentrations below $1 \mathrm{mg} / \mathrm{L}$, the higher-porosity shoal and backshoal facies retains more than $80 \%$ of the reduction capacity even for groundwater flow that started prior to the last interglacial (Fig. 6a). If the background $\mathrm{NO}_{3}{ }^{-}$is transported along fractures in the low-porosity basinal facies, the reduction capacity of the aquifer section becomes depleted after about ten thousand years (Fig. 6c).

When high anthropogenic $\mathrm{NO}_{3}{ }^{-}$concentrations are considered, which entered the groundwater as a consequence of the increased fertilizer application since the 1960s, the reduction capacity remains nearly unaltered for the shoal/ backshoal and tempestite facies (Fig. 6d, e). The results for the low-porosity basinal facies indicate a decrease to about 60-70\% after anthropogenic $\mathrm{NO}_{3}{ }^{-}$input of approximately 60 years (Fig. 6f). The preservation of the reduction potential in the tempestite, and particularly the shoal/backshoal facies, is a consequence of high matrix porosities - note that the effective diffusion coefficient $D_{\mathrm{e}}$ increases nonlinearly with porosity in Eq. (3). The higher the matrix porosity, the larger is the volume of the rock matrix that contributes to nitrate reduction and the larger is the quantity of available electron donors. This is indicated by the substantially larger penetration depth of the depletion front of $z_{\mathrm{m}}=38 \mathrm{~cm}$ in the shoal/backshoal rock matrix as compared to the basinal facies with $z_{\mathrm{m}}=0.07 \mathrm{~cm}$.

Calculating the average mineral depletion depth in the rock matrix for different porosities at $x=0$ yields: $z_{\mathrm{m}}\left(\mathrm{O}_{2}\right)+z_{\mathrm{m}}\left(\mathrm{NO}_{3}\right)=0.002$ to $1.1 \mathrm{~m}$, which is much smaller than the spacing of the fractures. This means that only a small part of the aquifer volume contributes to oxygen consumption and nitrate reduction and hence to the protection of the water supply well against a nitrate breakthrough.

The estimated $r_{\mathrm{PP}}$ values shown in Fig. 6 are based on the assumption that all electron donors are used up directly in the rock matrix in instantaneous reactions. Therefore, these estimates represent optimal conditions for the considered nitrate reduction scenarios. Lower $r_{\mathrm{PP}}$ values are expected in case of unfavourable conditions for mineral dissolution or reactivity, or if microbial access is limited because only a fraction of the electron donors is available for the reactions. Due to their generally low concentrations, sedimentary organic carbon and DOC are believed to be of no relevance for nitrate reduction in the Upper Muschelkalk aquifer. The maximum potential contribution of sedimentary organic carbon to nitrate reduction (e.g., by additional heterotrophic
Fig. 6 Remaining well-protective nitrate reduction potential $r_{\mathrm{PP}}($ in $\%$ ) as a function of the $\mathrm{NO}_{3}{ }^{-}$concentration (y-axis) and time (x-axis). a-c Contours for long-term natural $\mathrm{NO}_{3}{ }^{-}$input concentrations for the different facies. The dashed red line assumes low $\mathrm{NO}_{3}{ }^{-}$background values in groundwater $(1 \mathrm{mg} / \mathrm{L})$ over long periods of time. $\mathbf{d}-\mathbf{f}$ Contours for high $\mathrm{NO}_{3}{ }^{-}$concentrations resulting from anthropogenic $\mathrm{N}$ additions for the different facies. The dashed red line highlights the approximate time of high average $\mathrm{NO}_{3}{ }^{-}$concentrations in the study area $(35 \mathrm{mg} / \mathrm{L})$. Values for $t_{\mathrm{xm}}$ and $z_{\mathrm{m}}(x=0)$ refer to the time when the well-protective nitrate reduction will be entirely depleted $\left(r_{\mathrm{PP}}=0\right)$ and the depth the reaction front has propagated into the matrix at the upgradient boundary of the anoxic zone at this time
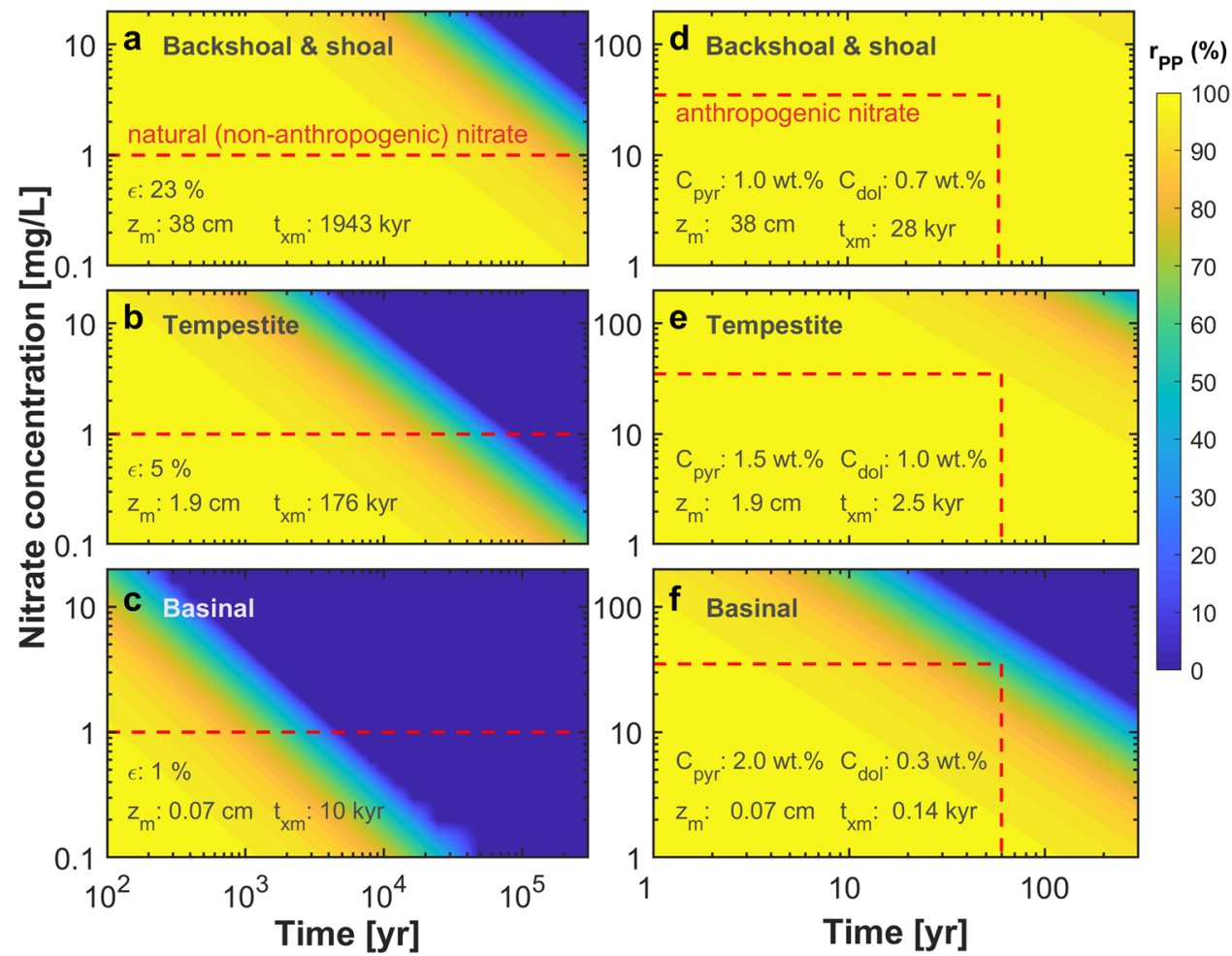
Fig. 7 Remaining well-protective nitrate reduction potential $r_{\mathrm{PP}}($ in $\%)$ as a function of the $\mathrm{NO}_{3}{ }^{-}$concentration and time, calculated for a larger fracture spacing of $d=40 \mathrm{~m}$ as compared to the base case in Fig. 6 $(d=10 \mathrm{~m})$. a-c Contours for long-term natural $\mathrm{NO}_{3}{ }^{-}$input concentrations for the different facies. The dashed red line assumes low $\mathrm{NO}_{3}{ }^{-}$background values in groundwater $(1 \mathrm{mg} / \mathrm{L})$ over long (but unknown) periods of time. $\mathbf{d}-\mathbf{f}$ Contours for high $\mathrm{NO}_{3}{ }^{-}$concentrations resulting from anthropogenic $\mathrm{N}$ additions for the different facies

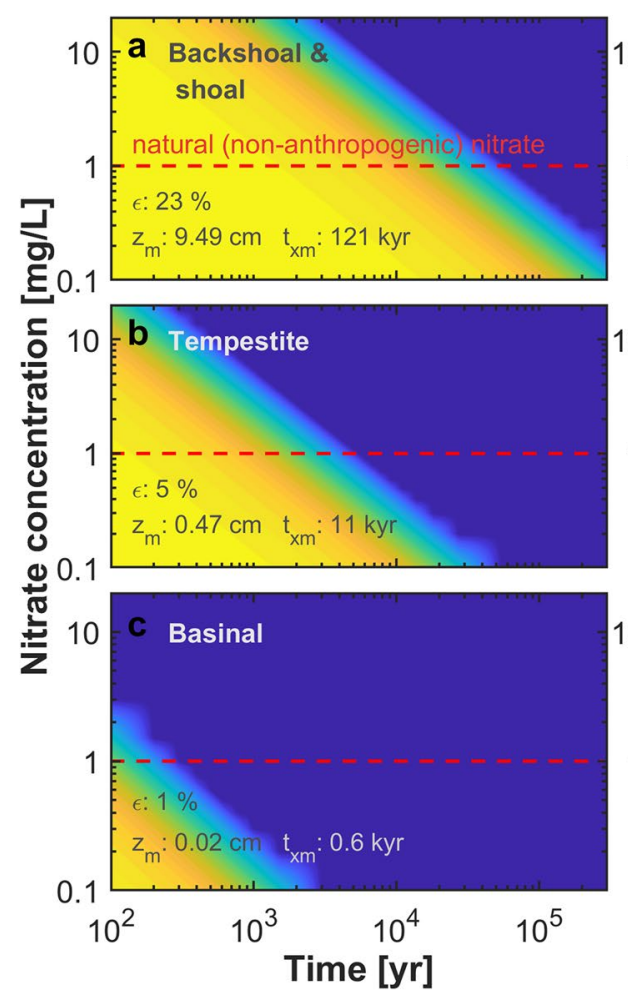

denitrification) would only amount to about $15 \%$ of the overall electron donor capacity assuming a mean $f_{\text {oc }}$ of $0.1 \mathrm{wt} . \%$ as was determined for the Upper Muschelkalk rock matrix.

The results shown in Fig. 6 are sensitive to the hydraulic aquifer parameters, $d, K$, and $I\left(r_{\mathrm{PP}}\right.$ depends on the square of these parameters); however, thanks to the well logging campaigns and previous work in the study area reported in D'Affonseca et al. (2020), these parameters could be estimated reasonably well. Against this background, it is believed that the $r_{\mathrm{PP}}$ values presented here represent good, but optimum estimates. However, the general trends are assumed to be well represented by Fig. 6, which also demonstrates the large differences between the facies types. Additional uncertainties remain due to often low accuracy of the contributing variables such as the hydraulic conductivity $K$.

The flowmeter logs of three investigated wells at the study site show that a large fraction of groundwater flow takes place in the backshoal facies. Since all wells are located in the confined part of the aquifer, about 5-10 km from the boundary of the uncovered oxic part, the modeling results indicate that for these wells the nitrate reduction potential can be expected to remain fully intact for at least several hundreds of years. However, if groundwater flow towards the wells also includes flow through bedding planes or fractures located in facies of lower porosity, the aquifer's nitrate reduction potential that can be utilized to protect the wells might diminish over a much shorter period of time. Figure 4 and Figs. S3 and S4 of ESM also show that total groundwater discharge is not distributed equally among the flow paths but is usually dominated by one of the contributing bedding planes. Under the assumption that discharge from all but one groundwater flow path is negligible, the calculation of $r_{\mathrm{PP}}$ using Eq. (11) has to account for an increase of the fracture spacing $d$ (by a factor equal to $n_{\mathrm{f}}=4$ ), in order to maintain the average hydraulic conductivity $K$ of the aquifer section. In this case, the reduction potential protecting a supply well in the basinal facies would be fully depleted already after 30 years of well operation for $\mathrm{NO}_{3}{ }^{-}$concentrations above $10 \mathrm{mg} / \mathrm{L}$ (Fig. 7). Although the aquifer has an almost infinite nitrate reduction potential, this again shows the large uncertainty in predicting reactive nitrate transport in such an aquifer system.

\section{Conclusions}

Based on investigations of the fractured Upper Muschelkalk aquifer in SW Germany, the nitrate reduction potential is mainly controlled by (1) the presence of $\mathrm{Fe}(\mathrm{II})$ or $\mathrm{S}(-\mathrm{I})$ bearing mineral phases such as pyrite, marcasite, or saddle dolomite formed under anaerobic conditions in shallow marine sediments or from percolating low-temperature hydrothermal fluids, (2) the diffusion coefficients and thus the matrix porosity of the different carbonate facies, and (3) the spacing of groundwater flow paths (along fractures or bedding planes) and their spatial interrelation with the 
different facies types. The major facies types show large differences in relevant parameters, and hence in the degradation of nitrate. With the simple electron acceptor/donor balance approach presented in this study, the nitrate reduction potential for water supply wells or other receptors of interest could be estimated. Using observed data from the study site, the results of the estimation show that concentrations of $\mathrm{Fe}(\mathrm{II})-$ minerals in the range of 1-4 wt.\% represent a high nitrate reduction potential and that to date only a minor part of the nitrate reduction potential of the fractured aquifer has been consumed. Particularly, if large parts of groundwater flow take place in high-porosity facies, the nitrate reduction capacity will most likely remain high over centuries. In contrast, if matrix porosities are low and flow is restricted to one or just as few fractures or bedding planes, then the nitrate reduction capacity protecting a well will be depleted within a few years to decades depending on nitrate concentration. These findings likely also apply for comparable fractured limestone aquifers which have been formed under similar conditions.

Supplementary Information The online version contains supplementary material available at https://doi.org/10.1007/s10040-021-02418-9.

Acknowledgements For support in the laboratory, we want to thank Bernice Nisch, Sara Cafisso, Annegret Walz, Per Jeisecke and Tatjana Miranda. Special thanks go to Andre Pellerin (Aarhus University) for sulfide analyses, to the staff of the Ammertal-Schönbuch Gruppe and personnel at the Herrenberg and Mötzingen quarries for providing access and technical support, and to the companies HydroTest Karch and Voutta Grundwasserhydraulik for support with borehole logging and sampling.

Funding Open Access funding enabled and organized by Projekt DEAL. This study was supported by the German Research Foundation (DFG) funded Collaborative Research Centre 1253 CAMPOS (Project 5: Fractured Aquifer) (DFG Grant Agreement SFB 1253/1).

\section{Declarations}

Conflict of interest On behalf of all authors, the corresponding author states that there is no conflict of interest.

Open Access This article is licensed under a Creative Commons Attribution 4.0 International License, which permits use, sharing, adaptation, distribution and reproduction in any medium or format, as long as you give appropriate credit to the original author(s) and the source, provide a link to the Creative Commons licence, and indicate if changes were made. The images or other third party material in this article are included in the article's Creative Commons licence, unless indicated otherwise in a credit line to the material. If material is not included in the article's Creative Commons licence and your intended use is not permitted by statutory regulation or exceeds the permitted use, you will need to obtain permission directly from the copyright holder. To view a copy of this licence, visit http://creativecommons.org/licenses/by/4.0/.

\section{References}

Agarwal JK, Olin JG (2014) Thermal anemometry. In: Webster JG, Eren $\mathrm{H}$ (eds) Measurement, instrumentation, and sensors handbook: spatial, mechanical, thermal, and radiation measurement, 2nd edn. CRC, Boca Raton, FL

Aigner T (1985) Storm depositional systems: dynamic stratigraphy in modern and ancient shallow-marine sequences. In: Lecture notes in earth sciences, vol 3. Springer, Berlin, $174 \mathrm{pp}$

Aigner T, Bachmann GH (1992) Sequence-stratigraphic framework of the German Triassic. Sediment Geol 80:115-135

Appelo CAJ, Postma D (2005) Geochemistry, groundwater and pollution, 2nd edn. CRC, Boca Raton, FL

Baker KM, Bottrell SH, Hatfield D, Mortimer RJG, Newton RJ, Odling NE, Raiswell R (2012) Reactivity of pyrite and organic carbon as electron donors for biogeochemical processes in the fractured Jurassic Lincolnshire limestone aquifer, UK. Chem Geol 332-333:26-31

Berner RA (1985) Sulphate reduction, organic matter decomposition and pyrite formation. Philos T R Soc London A 315:25-38

Bons PD, Fusswinkel T, Gomez-Rivas E, Markl G, Wagner T, Walter B (2014) Fluid mixing from below in unconformity-related hydrothermal ore deposits. Geology 42(12):1035-1038

Boving T, Grathwohl P (2001) Matrix diffusion coefficients in sandstones and limestones: relationship to permeability and porosity. J Cont Hydrol 53:85-100

Braun S (2003) Quantitative analysis of carbonate sandbodies: outcrop analog study from an epicontinental basin (Triassic Germany). $\mathrm{PhD}$ Theory, University of Tübingen, Germany

D'Affonseca FM, Michael F, Cirpka OA (2020) Combining implicit geological modeling, field surveys, and hydrogeological modeling to describe groundwater flow in a karst aquifer. Hydrogeol J 28:2779-2802

Davies G, Smith J (2006) Structurally controlled hydrothermal dolomite reservoir facies: an overview. AAPG Bull 90:1641-1690

Dunham RJ (1962) Classification of carbonate rocks according to depositional texture. In: Ham WE (ed) Classification of carbonate rocks: a symposium. AAPG Mem 1:108-121

Einsiedl F, Mayer B (2006) Hydrodynamic and microbial processes controlling nitrate in a fissured-porous karst aquifer of the Franconian Alb, southern Germany. Environ Sci Technol 40(21):6697-6702

Farnleitner AH, Wilhartitz I, Ryzinska G, Kirschner AKT, Stadler H, Burtscher MM, Hornek R, Szewzyk U, Herndl G, Mach RL (2005) Bacterial dynamics in spring water of alpine karst aquifers indicates the presence of stable autochthonous microbial endokarst communities. Environ Microbiol 7:1248-1259. https://doi. org/10.1111/j.1462-2920.2005.00810.x

Fossing H, Jorgensen BB (1989) Measurement of bacterial sulfate reduction in sediments: evaluation of a single-step chromium reduction method. Biogeochem 8:205-222. https://doi.org/10. 1007/BF00002889

Geyer O, Gwinner M (2011) Geologie von Baden-Württenberg [Geology of Baden-Württemberg, 5th edn.], Schweizerbart, Stuttgart, Germany, $627 \mathrm{pp}$

Goldscheider N, Chen Z, Auler AS, Bakalowicz M, Broda S, Drew D, Hartmann J, Jiang G, Moosdorf N, Stevanovic Z, Veni G (2020) Global distribution of carbonate rocks and karst water resources. Hydrogeol J 28(5):1661-1677

Grathwohl P (1998) Diffusion in natural porous media: contaminant transport, sorption/desorption and dissolution kinetics. Kluwer, Boston, MA, $224 \mathrm{pp}$

Gregg JM, Shelton KL (1990) Dolomitization and dolomite neomorphism in the back reef facies of the Bonneterre and Davis 
formations (Cambrian), southeast Missouri. J Sediment Petrol 60:549-562

Hagdorn H (1991) The Muschelkalk in Germany: an introduction. In: Hagdorn H (ed) Muschelkalk, a field guide. Korb Goldschneck, Stuttgart, Germany

Heffernan JB, Albertin AR, Fork ML, Katz BG, Cohen MJ (2012) Denitrification and inference of nitrogen sources in the karstic Floridan aquifer. Biogeosciences 9:1671-1690

Henson WR, Cohen MJ, Graham WD (2019) Spatially distributed denitrification in a karst springshed. Hydrol Process 33:1191-1203

Herrmann M, Opitz S, Harzer R, Totsche KU, Küsel K (2017) Attached and suspended denitrifier communities in pristine limestone aquifers harbor high fractions of potential autotrophs oxidizing reduced iron and sulfur compounds. Microb Ecol 74:264-277. https://doi.org/10.1007/s00248-017-0950-x

Hill D (1984) Diffusion coefficients of nitrate, chloride, sulphate and water in cracked and uncracked chalk. J Soil Sci 35:27-33

Husic A, Fox J, Adams E, Ford W, Agouridis C, Currens J, Backus J (2019) Nitrate pathways, processes, and timing in an agricultural karst system: development and application of a numerical model. Water Resour Res 55:2079-2103

Jakus N, Blackwell N, Osenbrück K, Straub D, Byrne JM, Wang Z, Glöckler D, Elsner M, Lueders T, Grathwohl P, Kleindienst S, Kappler A (2021) Nitrate removal by a novel autotrophic nitratereducing iron(II)-oxidizing culture isolated from a pyrite-rich limestone aquifer. Appl Environ Microbiol 87(16). https://doi. org/10.1128/AEM.00460-21

Kim JJ, Comstock J, Ryan P, Heindel C, Koenigsberger S (2016) Denitrification and dilution along fracture flowpaths influence the recovery of a bedrock aquifer from nitrate contamination. Sci Total Environ 569-570:450-468

Kleineidam S, Rügner H, Ligouis B, Grathwohl P (1999a) Organic matter facies and equilibrium sorption of phenanthrene. Environ Sci Technol 33:1637-1644

Kleineidam S, Rügner H, Grathwohl P (1999b) Influence of petrographic composition/ organic matter distribution of fluvial aquifer sediments on the sorption of hydrophobic contaminants. Sediment Geol 129:311-325

Kludt C, Weber FA, Bergmann A, Knöller K, Berthold G, Schüdt C (2016) Identifizierung der Nitratabbauprozesse und Prognose des Nitratabbaupotenzials in den Sedimenten des Hessischen Rieds [Identification of the nitrate degradation processes and prognosis of the nitrate degradation potential in the sediments of the Hessian Ried]. Grundwasser 21:227-241

Köhrer BS, Heymann C, Prousa F, Aigner T (2010) Multiplescale facies and reservoir quality variations within a dolomite body: outcrop analog study from the Middle Triassic, SW German Basin. Marine Petrol Geol 27:386-411

Korom SF (1992) Natural denitrification in the saturated zone: a review. Water Resour Res 28(6):1657-1668

Kostic B, Aigner T (2004) Sedimentary and poroperm anatomy of shallow-water carbonates (Muschelkalk, south-German Basin): an outcrop analogue study of inter-well spacing scale. Facies 50:113-131

Kuypers MMM, Marchant HK, Kartal B (2018) The microbial nitrogen-cycling network. Nat Rev Microbiol 16(5):263-276. https:// doi.org/10.1038/nrmicro.2018.9

LGRB (2019) Kartenviewer - Layer Geologische Übersichtskarte von Baden-Württemberg 1:300,000 [Map viewer - layer geological map of the state of Baden-Württemberg 1:300,000]. Landesamt für Geologie, Rohstoffe und Bergbau Baden-Württemberg, LGRB, Freiburg, Germany. http://maps.lgrb-bw.de/. Accessed 16 February 2021

Loschko M, Wöhling T, Rudolph DL, Cirpka OA (2019) An electronbalance based approach to predict the decreasing denitrification potential of an aquifer. Groundwater 57(6):925-939
Lübben A, Leven C (2018) The Starzach site in southern Germany: a site with naturally occurring $\mathrm{CO}_{2}$ emissions recovering from century-long gas mining as a natural analog for a leaking CCS reservoir. Environ Earth Sci 77:316

Machel HG, Lonnee J (2002) Hydrothermal dolomite: a product of poor definition and imagination. Sediment Geol 152:163-171

Morris BL, Lawrence ARL, Chilton PJC, Adams B, Calow RC, Klinck BA (2003) Groundwater and its susceptibility to degradation: a global assessment of the problem and options for management. Early Warning and Assessment Report Series, RS. 03-3, United Nations Environment Programme, Nairobi, Kenya, 126 pp. https:// wedocs.unep.org/handle/20.500.11822/8035. Accessed November 2021

Mosthaf K, Brauns B, Fjordboge AS, Rohde MM, Kerrn-Jespersen H, Bjerg PL, Binning PJ, Broholm MM (2018) Conceptualization of flow and transport in a limestone aquifer by multiple dedicated hydraulic and tracer tests. J Hydrol 561:532-546

OECD (2008) Environmental performance of agriculture in OECD countries since 1990. OECD, Paris, 576 pp. https://doi.org/10. 1787/9789264040854-en

Opazo T, Aravena R, Parker B (2016) Nitrate distribution and potential attenuation mechanisms of a municipal water supply bedrock aquifer. Appl Geochem 73:157-168

Orr A, Nitsche J, Archbold M, Deakin J, Ofterdinger U, Flynn R (2016) The influence of bedrock hydrogeology on catchment-scale nitrate fate and transport in fractured aquifers. Sci Total Environ 569-570:1040-1052

Palermo D, Aigner T, Seyfang B, Nardon S (2012) Reservoir properties and petrophysical modelling of carbonate sand bodies: outcrop analogue study in an epicontinental basin (Triassic, Germany). Geol Soc Lond Spec Publ 370:111-138

Pauwels H, Foucher JC, Kloppmann W (2000) Denitrification and mixing in a schist aquifer: influence on water chemistry and isotopes. Chem Geol 168:307-324

Pfaff K, Hildebrandt L, Leach D, Jacob D, Markl G (2010) Formation of the Wiesloch Mississippi Valley-type $\mathrm{Zn}-\mathrm{Pb}-\mathrm{Ag}$ deposit in the extensional setting of the Upper Rhinegraben, SW Germany. Mineral Deposita 45:647-666

Picioreanu C, van Loosdrecht MCM, Heijnen JJ (1997) Modelling the effect of oxygen concentration on nitrite accumulation in a biofilm airlift suspension reactor. Water Sci Technol 36(7):147-156

Radke BM, Mathis RL (1980) On the formation and occurrence of saddle dolomite. J Sediment Petrol 50:1149-1168

Reicherter K, Froitzheim N, Jaronsinski M, Badura J, Franzke HJ, Hansen M, Huebscher C, Müller R, Poprawa P, Reinecker J, Stackbrandt W, Voigt T, von Eynatten H, Zuckiewicz W (2008) Alpine tectonics north of the Alps. Mesozoic Cenozoic 2:1233-1286

Ring U, Bolhar R (2020) Tilting, uplift, volcanism and disintegration of the South German block. Tectonophysics 795:228611. https:// doi.org/10.1016/j.tecto.2020.228611

Rivas A, Singh R, Horne D, Roygard J, Matthews A, Hedley MJ (2017) Denitrification potential in the subsurface environment in the Manawatu River catchment, New Zealand: indications from oxidation-reduction conditions, hydrogeological factors, and implications for nutrient management. J Environ Manag 197:476-489

Rivett MO, Smith JWN, Buss SR, Morgan P (2007) Nitrate occurrence and attenuation in the major aquifers of England and Wales. Q J Eng Geol Hydrogeol 40:335-352. https://doi.org/10.1144/14709236/07-032

Rivett MO, Buss SR, Morgan P, Smith JWN, Bemment CD (2008) Nitrate attenuation in groundwater: a review of biogeochemical controlling processes. Water Res 42(16):4215-4232

Rügner H, Kleineidam S, Grathwohl P (1999) Long term sorption kinetics of phenanthrene in aquifer materials. Environ Sci Technol 33:1645-1651 
Schauer M, Aigner T (1997) Cycle stacking pattern, diagenesis and reservoir geology of peritidal dolostones, Trigonodus-dolomite, Upper Muschelkalk (Middle Triassic, SW-Germany). Facies 37:99-114

Schwarz HU (2012) Das Schwäbisch-Fränkische Bruchmuster [The Swabian-Franconian break pattern]. Zdt. Ges Geowiss 163:411-446

Schwientek M, Einsiedl F, Stichler W, Stögbauer A, Strauss H, Maloszewski P (2008) Evidence for denitrification regulated by pyrite oxidation in a heterogeneous porous groundwater system. Chem Geol 255:60-67

Sidborn M, Neretnieks I (2007) Long-term redox evolution in granitic rocks: modelling the redox front propagation in the rock matrix. Appl Geochem 22:2381-2396

Sidborn M, Neretnieks I (2008) Long-term oxygen depletion from infiltrating groundwaters: model development and application to intraglaciation and glaciation conditions. J Contam Hydrol 100:72-89

Smith RL, Duff JH (1988) Denitrification in a sand and gravel aquifer. Appl Environ Microbiol 54(5):1071-1078

Spötl C, Pitman JK (1998) Saddle (Baroque) dolomite in carbonates and sandstones: a reappraisal of a burial-diagenetic concept. Spec Publ Int 26:437-460

Starke R, Müller M, Gaspar M, Marz M, Küsel K, Totsche KU (2017) Candidate Brocadiales dominates $\mathrm{C}, \mathrm{N}$ and $\mathrm{S}$ cycling in anoxic groundwater of a pristine limestone-fracture aquifer. J Proteome 152:153-160

Staude S, Bons PD, Markl G (2009) Hydrothermal vein formation by extension-driven dewatering of the middle crust: an example from SW Germany. Earth Planet Sci Lett 286:387-395. https://doi.org/ 10.1016/j.epsl.2009.07.012

Straub KL, Benz M, Schink B, Widdel F (1996) Anaerobic, nitratedependant microbial oxidation of ferrous iron. Appl Environ Microbiol 62:1458-1460

Sültenfuß J, Roether W, Rhein M (2009) The Bremen mass spectrometric facility for the measurement of helium isotopes, neon, and tritium in water. Isot Environ Health Stud 45(2):83-95
Vías JM, Andreo B, Perles MJ, Carrasco F, Vadillo I, Jiménez P (2006) Proposed method for groundwater vulnerability mapping in carbonate (karstic) aquifers: the COP method. Hydrogeol J 14:912-925

Villinger E (1982) Grundwasserbilanzen im Karstaquifer des Oberen Muschelkalks im Oberen Gäu (Baden-Württemberg) [Groundwater balances in the karst aquifer of the Upper Muschelkalk in the “Oberes Gäu” area]. Geologisches Jahrbuch, C 32, BGR, Hannover, Germany

Visser AN, Lehmann MF, Rügner H, D'Affonseca FM, Grathwohl P, Blackwell N, Kappler A, Osenbrück K (2021) Fate of nitrate during groundwater recharge in a fractured karst aquifer in Southwest Germany. Hydrogeol J 29(3):1153-1171. https://doi.org/10.1007/ s10040-021-02314-2

Ward M, Jones R, Brender J, deKok T, Weyer P, Nolan B, Villanueva C, van Breda S (2018) Drinking water nitrate and human health: an updated review. Int J Env Res Pub He 15(7):1557

Warnecke M, Aigner T (2019) Asymmetry of an epicontinental basin: facies, cycles, tectonics and hydrodynamics: the Triassic Upper Muschelkalk, south Germanic Basin. Depos Rec 5:147-187

Zarnetske JP, Haggerty R, Wondzell SM, Baker MA (2011) Labile dissolved organic carbon supply limits hyporheic denitrification. J Geophys Res 116:G04036

Zeeh S, Geng A (2001) Entstehung und Diagenese von Dolomit in der Muschelkalk-Gruppe (Mitteltrias) SW-Deutschlands [Formation and diagenesis of dolomite in the Muschelkalk group (Central Triassic) SW Germany]. Neues Jahrb Geol P-A 221:359-395

Zhang YC, Prommer H, Broers HP, Slomp CP, Greskowiak J, van der Grift B, Van Cappellen P (2013) Model-based integration and analysis of biogeochemical and isotopic dynamics in a nitratepolluted pyritic aquifer. Environ Sci Technol 47:10415-10422

Ziegler PA (1990) Geological atlas of Western and Central Europe, 2nd edn. Shell International Petroleum Maatschappij, The Hague

Publisher's note Springer Nature remains neutral with regard to jurisdictional claims in published maps and institutional affiliations. 